\title{
Application of the NUFT Code for Subsurface Remediation by Bioventing
}

\author{
Y. Sun, Z. Demir, T. Delorenzo and J.J. Nitao
}

U.S. Department of Energy

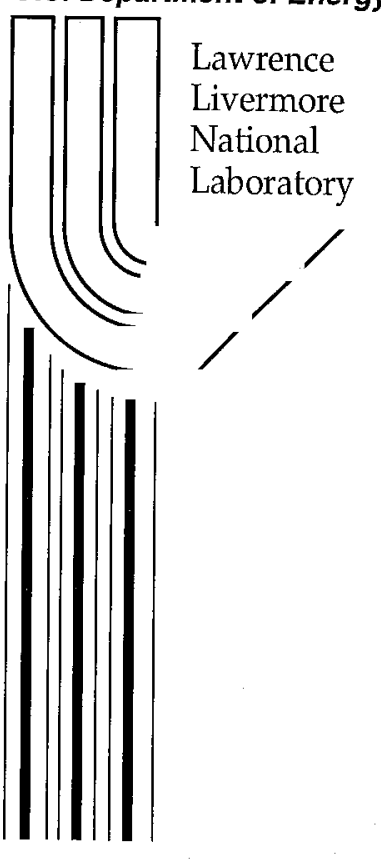

March 2, 2000 


\section{DISCLAIMER}

This document was prepared as an account of work sponsored by an agency of the United States Government. Neither the United States Government nor the University of California nor any of their employees, makes any warranty, express or implied, or assumes any legal liability or responsibility for the accuracy, completeness, or usefulness of any information, apparatus, product, or process disclosed, or represents that its use would not infringe privately owned rights. Reference herein to any specific commercial product, process, or service by trade name, trademark, manufacturer, or otherwise, does not necessarily constitute or imply its endorsement, recommendation, or favoring by the United States Government or the University of California. The views and opinions of authors expressed herein do not necessarily state or reflect those of the United States Government or the University of California, and shall not be used for advertising or product endorsement purposes.

Work performed under the auspices of the U.S. Department of Energy by the University of California Lawrence Livermore National Laboratory under Contract W-7405-Eng-48.

This report has been reproduced directly from the best available copy.

Available to DOE and DOE contractors from the Office of Scientific and Technical Information

P.O. Box 62, Oak Ridge, TN 37831

Prices available from (423) 576-8401 http://apollo.osti.gov/bridge/

Available to the public from the National Technical Information Service

U.S. Department of Commerce 5285 Port Royal Rd., Springfield, VA 22161

http://www.ntis.gov/

OR

Lawrence Livermore National Laboratory Technical Information Department's Digital Library http://www.llnl.gov/tid/Library.html 


\title{
Application of the NUFT Code for Subsurface Remediation by Bioventing
}

\author{
Yunwei Sun, Zafer Demir, Truc Delorenzo \\ Weiss Associates \\ John J. Nitao \\ Lawrence Livermore National Laboratory
}

March 2, 2000 


\section{DISCLAIMER}

This document was prepared as an account of work sponsored by an agency of the United States Government. Neither the United States Government nor the University of California nor any of their employees, makes any warranty, express or implied, or assumes any legal liability or responsibility for the accuracy, completeness, or usefulness of any information, apparatus, product, or process disclosed, or represents that its use would not infringe privately owned rights. Reference herein to any specific commercial product, process, or service by trade name, trademark, manufacturer, or otherwise, does not necessarily constitute or imply its endorsement, recommendation, or favoring by the United States Government or the University of California. The views and opinions of authors expressed herein do not necessarily state or reflect those of the United States Government or the University of California, and shall not be used for advertising or product endorsement purposes. 


\title{
Application of the NUFT Code for Subsurface Remediation by Bioventing
}

\author{
Yunwei Sun \\ Zafer Demir \\ Truc Delorenzo \\ Weiss Associates, Emeryville, California \\ John J. Nitao \\ Geosciences and Environmental Technologies Division, \\ Lawrence Livermore National Laboratory, \\ Livermore, California
}

March 2, 2000 


\section{Acknowledgments}

This work was funded by the DOD/DOE Strategic Environmental Research and Development Program (SERDP) as part of a project directed by the U.S. Army Engineer Research and Development Center, Waterways Experiment Station (WES), Vicksburg, Mississippi. We would like to thank Dr. Mark Dortch at WES, without whom this work would not have been possible. Our thanks, also, go to Sam Johnson at Hill Air Force Base and Marc S. Greeley of Montgomery Watson for kindly providing the site characterization and remediation data that is used in this report.

Work performed at LLNL is under the auspices of the U.S. Department of Energy, under Contract W-7405-Eng-48. 


\section{Introduction}

Bioventing (BV) is a promising, cost-effective technology for the biodegradation of soil contaminated with petroleum hydrocarbons. The goal of BV is to stimulate naturally-occurring soil microorganisms to degrade organic contaminants in the soil. In natural systems the rate of biodegradation is eventually limited by the lack of oxygen and other electron acceptors (i.e., a compound that gains electrons during biodegradation) rather than by the lack of nutrients (i.e., electron donors). In conventional bioventing systems, oxygen is delivered by an electric blower to subsurface wells. The airflow rate is usually low in contrast to soil vapor extraction, just enough to provide sufficient oxygen to maintain or enhance microbial activity.

In order to design a bioventing system wisely, decision makers should understand the role that design variables may play. Those design variables include locations of injection wells, injection rates, air pressure and moisture at wells, water table control, monitoring well locations, etc. Trade-off between these variables should be made before the implementation of a bioventing system. Obviously, the mathematical model corresponding to the multiphase flow and multi-species reactive transport is essential to describing the relations between design variables and system response.

Lawrence Livermore National Laboratory (LLNL) is subcontracted by the DOD/DOE Strategic Environmental Research and Development Program (SERDP) under the direction of the U. S. Army Engineer Research and Development Center, Vicksburg, Mississippi, to leverage and share expertise in subsurface contaminant remediation technology. This particular project consists of the validation of the NUFT code against field remediation data for bioventing.

The work phases for the project are: (Phase 1) building biodegradation simulation capabilities into the NUFT code and documentation, (Phase 2) determining a well-characterized and evaluated bioventing remediation site for field validation, (Phase 3) obtaining and analyzing the field data, (Phase 4) setting up the conceptual model, (Phase 5) implementing the simulation input consistent with the conceptual model, and (Phase 6) demonstrating the performance of the code by comparing it to data from the remediation site. At the time of this report, most of Phases 1,2,4,5, and portions of Phase 3 and 6 were completed. 


\section{Objectives}

This particular project focuses on developing a comprehensive modeling framework to model bioventing remediation data collected at the Hill AFB site 280 . Due to the complex nature of the transport and reactive subsurface system undergoing bioventing actions, multiphase and multi-species reactive transport simulation is needed to accurately reflect mass transport, phase-partitioning, biochemical reactions and to quantify the effectiveness of the bioventing system design. Although there are several numerical codes available in the literature for modeling reactive transport (Borden and Bedient, 1986; Molz et al., 1986; Shoemaker et al., 1990; Culver et al., 1991; McNab and Narasimhan, 1993; Rifai and Bedient, 1990; Xu et al., 1997; Clement et al., 1998; Waddill and Widdowson, 1998; Nitao, 1998b; Sun et al., 1998; Xu et al., 1999; Baehr et al., 1999), they are limited either to single-phase transport with multi-species reactions or to simple unrealistic reactions with phase-partitioning.

In this study, we include the mathematical formulation of biodegradation processes of hydrocarbons that have been incorporated into the NUFT code for simulating bioventing remediation and validate the code against field data. We initially completed an extensive search among DOD/DOE facilities where bioventing was selected as the remedial alternative. There are several sites that met the criteria for adequate site characterization and extensive monitoring where a representative numerical model can be developed and simulations can be calibrated. The Hill Air Force Base (Hill AFB) was selected to validate the NUFT code for bioventing. Sites 260, 280 and 870 from Hill AFB were evaluated and the bioventing project at Site 280 was selected for field validation.

\section{General Description of NUFT}

NUFT (Non-isothermal Unsaturated-saturated Flow and Transport model) is a generalized multipurpose computer code for modeling multiphase fluid flow and multi-species reactive transport in porous media under both nonisothermal and isothermal conditions (Nitao, 1998a; 1998b). It solves the partial differential equations for the conservation of mass and energy. NUFT is an efficient and robust code that has been used to simulate a wide range of computationally demanding problems. NUFT consists of several modules described previously in a single source code instead of multiple source versions. Each module has its own set of simplifying assumptions so that the user can select the most physically appropriate mathematical module and com- 
putationally efficient numerical solution method. The model input format is user-friendly, flexible, and upwardly compatible.

USNT is one of the NUFT modules (Nitao, 1998b). It solves the multiphase flow and multi-species transport equations under non-isothermal conditions. Those transport equations may be coupled by both equilibrium-based and kinetics-based reactions, such as the first-order, sequentially first-order, Monod, and dual-substrate Monod reactions. In Hill AFB bioventing project, an irreversible dual-substrate Monod reaction kinetics is used.

\section{Case Study Hill A.F.B. Bioventing Project - Site 280}

\section{Introduction}

Hill Air Force Base is located 10 miles south of Ogden, Utah. At Site 280 in the Base, the vadose zone has been contaminated by a JP-4 jet fuel spill. Research conducted at the site by Base personnel and subcontractors indicates that JP-4 is aerobically biodegradable in the vadose zone soils (Battelle, 1992). However, naturally-supplied oxygen through soil aeration has become the primary limiting factor of the biodegradation processes. One of the promising alternatives is to inject air into the contaminated soil to enhance aerobic bioremediation. The source of the contamination is the 280 Fuel Storage Lot, which has been in operation since the 1940's. The underground storage tanks have either been removed or replaced with new tanks. The Fuel Storage Lot Site is located in deltaic sediments, consisting predominantly of sand. Various clayey, silty, and gravely sand zones are encountered during boring. Due to limited precipitation (approximately 19 inches annually) and high evapotranspiration rates, shallow ground water only occurs in discontinuous perched zones. Soil moisture averages less than $6 \%$ in the unsaturated zone. Average ground elevation is $4780 \mathrm{ft}$ above mean sea level. The first shallow ground water at the 280 Fuel Storage Lot Site lies approximately 100 feet below ground surface. The ground water gradient beneath the site is between 0.017 to 0.020 towards the east (Battelle, 1991).

Site 280 currently has 9 soil gas monitoring wells, seven surface monitoring points, and one injection well. Figure 1 shows the location of bioventing wells and radius of bioventing influence. Long term monitoring indicated that $60 \%$ mass was removed due to volatilization and $40 \%$ due to biodegradation through bioventing (Montgomery Watson, 1995).

Bioventing injection well, 280-IW, was implemented with a $75 \mathrm{ft}$ screen and 


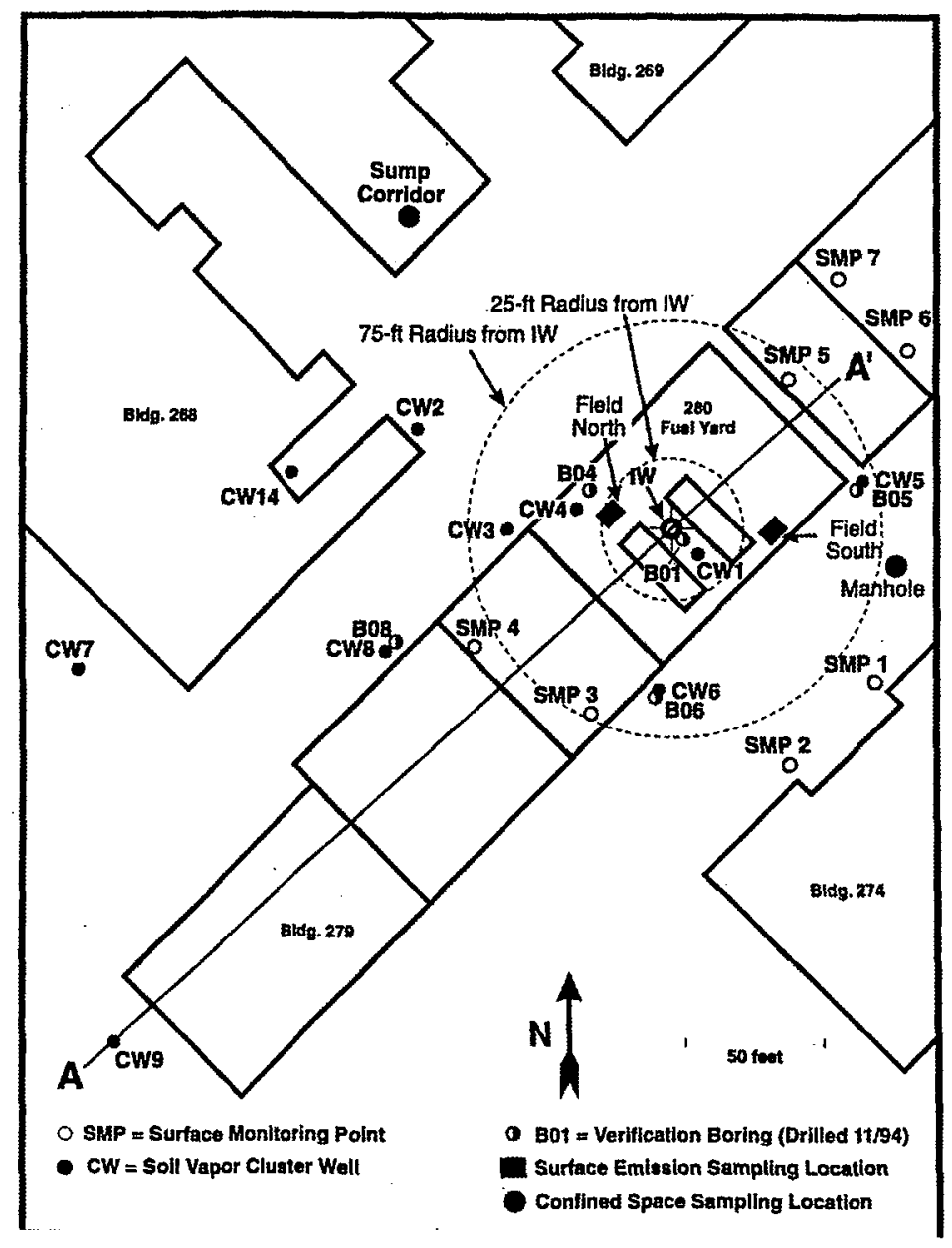

Figure 1: Site map, location of bioventing wells and radius of bioventing influence. 
a total depth of $108.2 \mathrm{ft}$-bgs. A 4 inch ID PVC screen was used. The bore hole diameter was 14.5 inch, giving an annulus of 4 to 5 inches for the sand pack.

Site hydrogeological information is derived from borehole geological logs (Battelle, 1992) and is shown in Table 3 through Table 6. The geological formation at the site is shown in Figure 2 and Tables 1 through 2. Moisture content is shown in Figure 3 (Dupont et al., 1995).

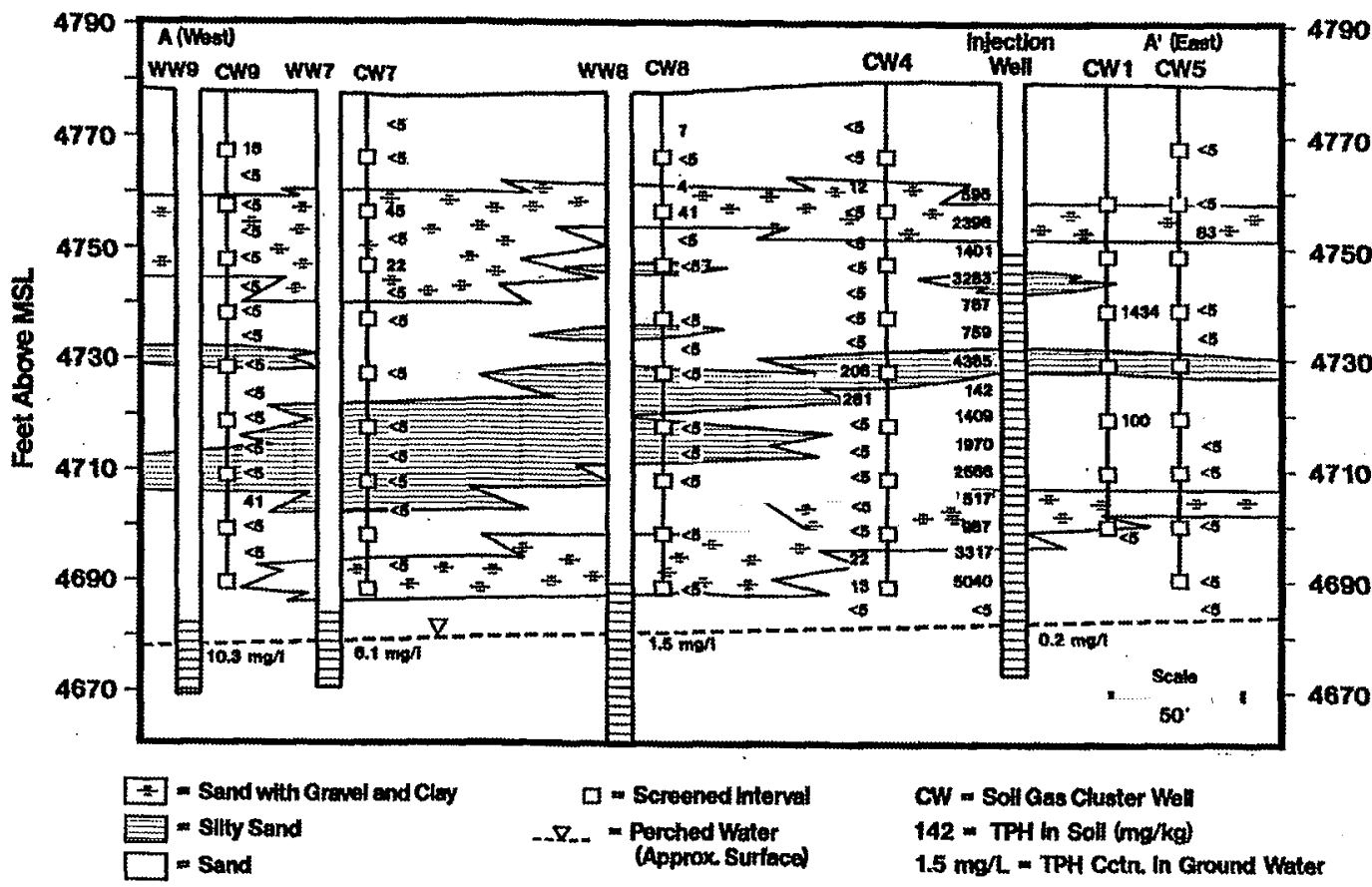

Figure 2: Geological cross section of Site 280.

General information can be summarized from site reports:

- CPT hydraulic conductivity estimates at $\sim 35 \mathrm{ft}-\mathrm{bgs}: 1.0 \mathrm{e}-4 \mathrm{~cm} / \mathrm{sec}$ (1.02e-13 $\mathrm{m}^{2} \sim 1 \mathrm{e}-6 \mathrm{~m} / \mathrm{sec}$ ) (Battelle, 1993).

- Air permeability of $5.6 \mathrm{e}-10 \mathrm{~cm}^{2}\left(5.6 \mathrm{e}-14 \mathrm{~m}^{2} \sim 5.6 \mathrm{e}-7 \mathrm{~m} / \mathrm{sec}\right)$ with a radius of influence of $200 \mathrm{ft}$ (Battelle, 1994). 


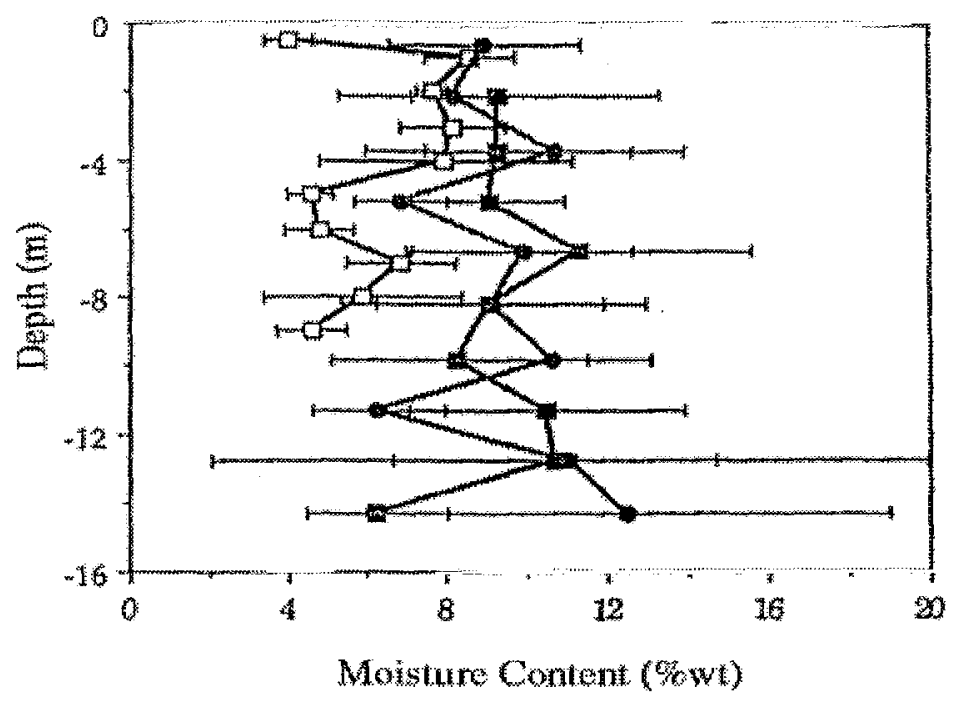

Figure 3: Mean soil moisture content at Hill AFB, UT, before, after irrigation and nutrient application at the field site.

Table 1: Soil types by depth in the vicinity of the injection well (250 ft radius) SW-sand: well graded, gravely, SP-sand: poorly graded, no gravel, SM-sand: silty, sand-silt mixture, CL-clays: with sand and silt.

\begin{tabular}{|c|c|c|c|c|c|c|c|c|c|c|c|}
\hline IW & & CW1 & & CW2 & & CW3 & & CW4 & & W5 & \\
\hline $0-25$ & SW & & & $0-20$ & SP & $0-20$ & SP & $0-20$ & SP & $0-20$ & SP \\
\hline $25-45$ & SP & $20-70$ & SW & $20-30$ & SW & $20-80$ & SW & $20-30$ & SW & $20-25$ & SW \\
\hline $45-50$ & SW & & & $30-40$ & SP & & & $30-50$ & $\mathrm{SM}$ & $25-50$ & SM \\
\hline $50-60$ & $\mathrm{SP}$ & & & $40-50$ & SW & & & $50-75$ & SP & $50-55$ & SP \\
\hline $60-90$ & SW & $70-90$ & $\mathrm{SP}$ & $50-60$ & $\mathrm{SP}$ & $80-90$ & CL & $75-85$ & SW & $55-75$ & $\mathrm{SP}$ \\
\hline $0-110$ & SP & & & $60-90$ & SW & & & $85-90$ & SP & $75-80$ & SW \\
\hline
\end{tabular}


Table 2: Generalized cross-sectional geology within a radius of $250 \mathrm{ft}$ of injection well 280-IW: (Battelle, 1995)

\begin{tabular}{|l|l|l|}
\hline $0-20 \mathrm{ft}-\mathrm{bgs}$ & SP & Sand \\
\hline $20-30 \mathrm{ft}-\mathrm{bgs}$ & SW & Sand with gravel and clay \\
\hline $30-50 \mathrm{ft}$ bgs & SP & Sand \\
\hline $50-55 \mathrm{ft}-\mathrm{bgs}$ & SM & Silty sand \\
\hline $55-75 \mathrm{ft}-\mathrm{bgs}$ & SP & Sand \\
\hline $75-85 \mathrm{ft}-\mathrm{bgs}$ & SW & Sand with gravel and clay \\
\hline $85-110 \mathrm{ft}-\mathrm{bgs}$ & SP & Sand \\
\hline
\end{tabular}

- k-permeability data can be back calculated from existing data in report (Battelle, 1995).

- Saturated K for lean clay $=1.3 \mathrm{e}-7 \mathrm{~cm} / \mathrm{sec}\left(1.4 \mathrm{e}-16 \mathrm{~m}^{2} \sim 1.3 \mathrm{e}-9 \mathrm{~m} / \mathrm{sec}\right)$ (Montgomery, 1994).

- Slug tests from 5 wells yielded and average hydraulic conductivity of $0.0085 \mathrm{~cm} / \mathrm{sec}\left(8.7 \mathrm{e}-12 \mathrm{~m}^{2} \sim 8.5 \mathrm{e}-5 \mathrm{~m} / \mathrm{sec}\right)$ (Wiedemeier et al., 1995).

- Slug test results for saturated hydraulic conductivity ranges from 0.43 to $52.5 \mathrm{ft} /$ day $\left(1.5 \mathrm{e}-12 \mathrm{~m}^{2} \sim 1.5 \mathrm{e}-5 \mathrm{~m} / \mathrm{sec}\right.$ to $\left.1.9 \mathrm{e}-11 \mathrm{~m}^{2} \sim 1.85 \mathrm{e}-4 \mathrm{~m} / \mathrm{sec}\right)$ for five tests. Average was $19.3 \mathrm{ft} /$ day $\left(6.9 \mathrm{e}-12 \mathrm{~m}^{2} \sim 6.8 \mathrm{e}-05 \mathrm{~m} / \mathrm{sec}\right)(\mathrm{Lu}$ et al., 1999).

- Grain size analysis from deep interbedded clay to silty-clay samples: 7090\% passed No. 200 US standard sieve. Samples are defined as silt (Wiedemeier et al., 1995).

- Retardation coefficient of 1.35 (1.3 1.4) for benzene (less sorptive within BTEX) and 3.0 (2.7-3.4) for ethylbenzene (most sorptive within BTEX) (Wiedemeier et al., 1995).

- Porosity (assumed) 0.25 (Battelle, 1994; Wiedemeier et al., 1995).

- Total organic carbon (TOC) background 0.069 to $0.094 \%$ (Wiedemeier et al., 1995).

Detailed information of soil physical and chemical properties is shown as NUFT input in Table 3 through 6 and Figure 4. 


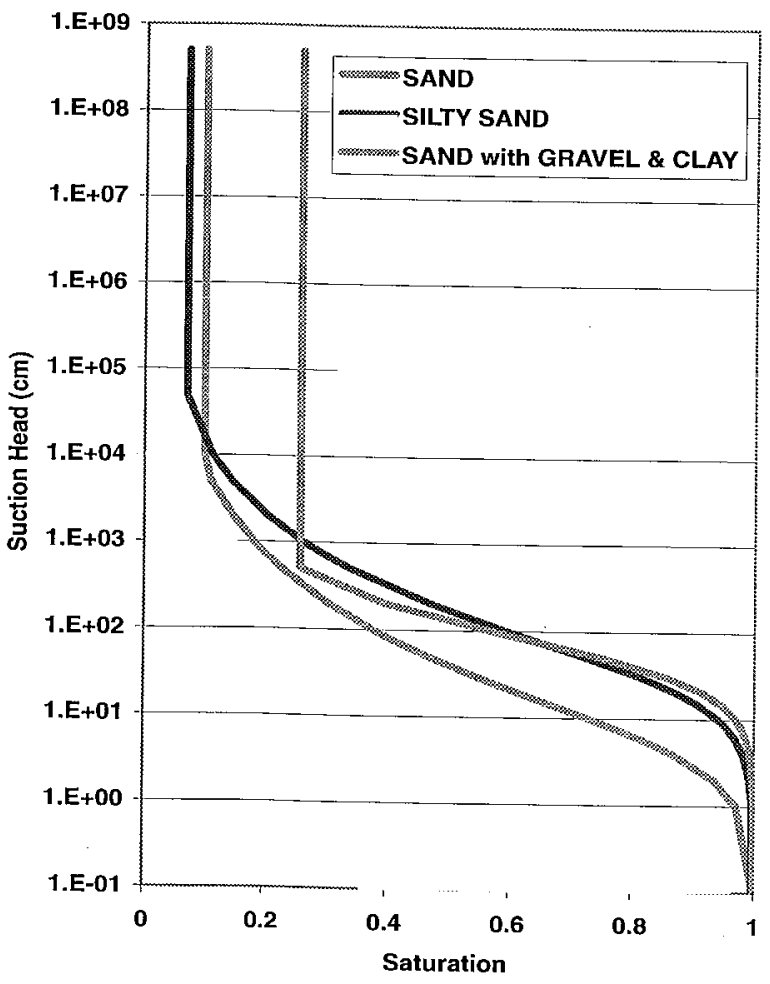

Figure 4: Hill AFB moisture retention curves. 
Table 3: Physical Properties of Sand

\begin{tabular}{|c|c|c|c|}
\hline Parameter & Units & Value & Reference \\
\hline $\begin{array}{l}\text { Saturated hydraulic } \\
\text { conductivity }\end{array}$ & $\mathrm{m}^{2}$ & $8.7 \mathrm{e}-12$ & {$[26]$} \\
\hline Soil density & $\mathrm{kg} / \mathrm{m}^{3}$ & 2650 & {$[27]$} \\
\hline Bulk density & $\mathrm{kg} / \mathrm{m}^{3}$ & 1630 & {$[27]$} \\
\hline Porosity & $\%$ & 0.25 & {$[26]$} \\
\hline$S_{r}$ & $\%$ & 0.06 & {$[26]$} \\
\hline$m(m=1-1 / n)$ & & $0.53 n=2.14$ & {$[24]$} \\
\hline$\alpha$ & $1 / \mathrm{m}$ & 14 & {$[24]$} \\
\hline$S_{a}$ & & 0.94 & {$[24]$} \\
\hline$K_{d}(\mathrm{~B})$ & $\mathrm{L} / \mathrm{kg}$ & 0.071 foc $=0.0009, \mathrm{Koc}=79 \mathrm{~L} / \mathrm{kg}$ & {$[27]$} \\
\hline$K_{d}(\mathrm{~T})$ & $\mathrm{L} / \mathrm{kg}$ & 0.171 foc $=0.0009, \mathrm{Koc}=190 \mathrm{~L} / \mathrm{kg}$ & {$[27]$} \\
\hline$K_{d}(\mathrm{E})$ & $\mathrm{L} / \mathrm{kg}$ & 0.421 foc $=0.0009, \mathrm{Koc}=468 \mathrm{~L} / \mathrm{kg}$ & {$[27]$} \\
\hline$K_{d}(\mathrm{X})$ & $\mathrm{L} / \mathrm{kg}$ & 0.321 foc $=0.0009, \mathrm{Koc}=357 \mathrm{~L} / \mathrm{kg}(\mathrm{p}-)$ & {$[27]$} \\
\hline$K_{d}\left(\mathrm{I}^{\prime} \mathrm{PH}\right)$ & $\mathrm{L} / \mathrm{kg}$ & & \\
\hline
\end{tabular}

\section{Mathematical model}

Mass balance equations of multi-species are used to describe the bioventing systems. In this study, we model the following components: $\mathrm{H}_{2} \mathrm{O}, \mathrm{O}_{2}, \mathrm{CO}_{2}$, $N_{2}$, and $C_{6} H_{6}$ (benzene). The nitrogen $\left(N_{2}\right)$ component represents that part of the air which is not $\mathrm{O}_{2}$ nor $\mathrm{CO}_{2}$, and is needed to close the flow equations. All components can partition in both the gaseous and aqueous phases, which allows, for instance, the evaporation of water, and dissolution of benzene in the aqueous phase. Both diffusive and advective transport of all components is considered. Since there is believed to be no NAPL phases at the site, no NAPL phase was included in the model.

Assuming nondeformable solid phase, the mass balance of species $\gamma$ is (Bear, 1979, Nitao, 1998b)

$$
\begin{aligned}
\frac{\partial}{\partial t}\left[\sum_{\alpha}^{l, g} \phi \rho_{\alpha} S_{\alpha} \omega_{\alpha}^{\gamma}+\rho_{B} k_{d}^{\gamma} \rho_{l} \omega_{l}^{\gamma}\right]= \\
\quad-\sum_{\alpha}^{l, g} \nabla \cdot S_{\alpha}\left(\rho_{\alpha} \omega_{\alpha}^{\gamma} \mathbf{V}_{\alpha}+\mathbf{J}_{\alpha}^{\gamma}+\mathbf{J}_{\alpha}^{* \gamma}\right)-f^{\gamma}
\end{aligned}
$$


Table 4: Physical Properties of Silty Sand

\begin{tabular}{|c|c|c|c|}
\hline Parameter & Units & Value & Reference \\
\hline $\begin{array}{l}\text { Saturated hydraulic } \\
\text { conductivity }\end{array}$ & $\mathrm{m}^{2}$ & $7.0 e-14$ & {$[27]$} \\
\hline Soil density & $\mathrm{kg} / \mathrm{m}^{3}$ & 2650 & {$[27]$} \\
\hline Bulk density & $\mathrm{kg} / \mathrm{m}^{3}$ & 1360 & {$[27]$} \\
\hline Porosity & $\%$ & 0.25 possibly less & {$[26]$} \\
\hline$S_{r}$ & $\%$ & 0.06 & {$[26]$} \\
\hline$m(m=1-1 / n)$ & & $0.27 \mathrm{n}=1.37$ & {$[24]$} \\
\hline$\alpha$ & $1 / \mathrm{m}$ & 1.6 & {$[24]$} \\
\hline$S_{a}$ & & 0.94 & {$[24]$} \\
\hline$K_{d}(\mathrm{~B})$ & $\mathrm{L} / \mathrm{kg}$ & 0.071 foc $=0.0009, \mathrm{Koc}=79 \mathrm{~L} / \mathrm{kg}$ & {$[27]$} \\
\hline$K_{d}(\mathrm{~T})$ & $\mathrm{L} / \mathrm{kg}$ & 0.171 foc $=0.0009, \mathrm{Koc}=190 \mathrm{~L} / \mathrm{kg}$ & {$[27]$} \\
\hline$K_{d}(\mathrm{E})$ & $\mathrm{L} / \mathrm{kg}$ & 0.421 foc $=0.0009, \mathrm{Koc}=468 \mathrm{~L} / \mathrm{kg}$ & {$[27]$} \\
\hline$K_{d}(\mathrm{X})$ & $\mathrm{L} / \mathrm{kg}$ & $0.321 \mathrm{foc}=0.0009, \mathrm{Koc}=357 \mathrm{~L} / \mathrm{kg}\left(\mathrm{p}^{-}\right)$ & {$[27]$} \\
\hline$K_{d}(\mathrm{TPH})$ & $\mathrm{L} / \mathrm{kg}$ & & \\
\hline
\end{tabular}

where Fickian Laws for dispersive and diffusive fluxes are given by

$$
\begin{aligned}
& \mathbf{J}_{\alpha}^{\gamma}=-\mathbf{D}_{h \alpha}^{\gamma} \nabla \rho_{\alpha} \omega_{\alpha}^{\gamma} \\
& \mathbf{J}_{\alpha}^{* \gamma}=-\rho_{\alpha} D_{\alpha}^{* \gamma} \nabla \omega_{\alpha}^{\gamma}
\end{aligned}
$$

and Darcy's law

$$
S_{\alpha} \phi \mathbf{V}_{\alpha}=-\underset{\mu_{\alpha}}{k_{\alpha}\left(S_{\alpha}\right)} \cdot\left(\nabla p_{\alpha}+\rho_{\alpha} g \nabla z\right)
$$

The retention pressure, (capillary pressure) relationships are given by

$$
p_{\alpha}=p_{g}-p_{c \alpha}\left(S_{\alpha}\right) .
$$

$f^{\gamma}[1 / T]$ is the reaction rate. The biochemical reactions are assumed to occur only in aqueous phase. The stoichiometry of the biodegradation process can be described by the following biochemical reaction:

$$
\mathrm{C}_{6} \mathrm{H}_{6}+7.5 \mathrm{O}_{2} \Rightarrow 6 \mathrm{CO}_{2}+3 \mathrm{H}_{2} \mathrm{O} \text {. }
$$


Table 5: Physical Properties of Sand with gravel and clay

\begin{tabular}{|c|c|c|c|}
\hline Parameter & Units & Value & Reference \\
\hline $\begin{array}{l}\text { Saturated hydraulic } \\
\text { conductivity }\end{array}$ & $\mathrm{m}^{2}$ & $7.0 e-13$ & {$[27]$} \\
\hline Soil density & $\mathrm{kg} / \mathrm{m}^{3}$ & 2650 & {$[27]$} \\
\hline Bulk density & $\mathrm{kg} / \mathrm{m}^{3}$ & 1725 & {$[27]$} \\
\hline Porosity & $\%$ & 0.25 possibly less & {$[26]$} \\
\hline$S_{r}$ & $\%$ & 0.06 & {$[26]$} \\
\hline$m(m=1-1 / n)$ & & $0.27 \mathrm{n}=1.37$ & {$[24]$} \\
\hline$\alpha$ & $1 / \mathrm{m}$ & 7.5 & {$[24]$} \\
\hline$S_{a}$ & & 0.94 & {$[24]$} \\
\hline$K_{d}(\mathrm{~B})$ & $\mathrm{L} / \mathrm{kg}$ & 0.071 foc $=0.0009, \mathrm{Koc}=79 \mathrm{~L} / \mathrm{kg}$ & {$[27]$} \\
\hline$K_{d}(\mathrm{~T})$ & $\mathrm{L} / \mathrm{kg}$ & 0.171 foc $=0.0009, \mathrm{Koc}=190 \mathrm{~L} / \mathrm{kg}$ & {$[27]$} \\
\hline$K_{d}(\mathrm{E})$ & $\mathrm{L} / \mathrm{kg}$ & 0.421 foc $=0.0009, \mathrm{Koc}=468 \mathrm{~L} / \mathrm{kg}$ & {$[27]$} \\
\hline$K_{d}(\mathrm{X})$ & $\mathrm{L} / \mathrm{kg}$ & 0.321 foc $=0.0009$, Koc $=357 \mathrm{~L} / \mathrm{kg}(\mathrm{p}-)$ & {$[27]$} \\
\hline$K_{d}(\mathrm{TPH})$ & $\mathrm{L} / \mathrm{kg}$ & & \\
\hline
\end{tabular}

In the reaction package, dual-Monod equations are implemented to describe biomass utilization of organic substrates (e.g., BTEX) and oxygen (Sun et al., 1998):

$$
\begin{aligned}
& f^{c}=X \mu_{\max }\left(\begin{array}{c}
c \\
K_{c}+c
\end{array}\right)\left(\frac{o}{K_{o}+o}\right) \\
& f^{o}=f \cdot f^{c}
\end{aligned}
$$

The various variables are defined in Table 7 . Since constant biomass concentration is assumed in (7), we define the reaction rate as

$$
\beta=X \mu_{\max } .
$$

As demonstrated by Sun et al. (1998), the dual-substrate Monod reaction with constant biomass concentration in (7) is relatively conservative kinetic format compared with instantaneous reactions or with the kinetic model with biomass growth and transport. The actual effectiveness of bioventing remediation could be equal or higher than the model prediction. 
Table 6: Chemicals of concern and properties

\begin{tabular}{|c|c|c|c|c|c|c|}
\hline Parameter & Unit & $\mathrm{B}$ & $\mathrm{T}$ & $\mathrm{E}$ & $\mathrm{X}(\mathrm{m}, \mathrm{o}, \mathrm{p})$ & $\begin{array}{l}\text { TPH } \\
\text { fresh } \\
\text {-weathered }\end{array}$ \\
\hline Solubility & $\mathrm{mg} / \mathrm{l}$ & 1780 & 515 & 152 & $200,170,198$ & \\
\hline $\begin{array}{l}\text { Henry's } \\
\text { Constant }\end{array}$ & $\operatorname{atm} \cdot \mathrm{m}^{3} / \mathrm{mol}$ & $5.43 \mathrm{e}-3$ & $6.61 \mathrm{e}-3$ & $2.28 \mathrm{e}-3$ & $\begin{array}{l}6.91 \mathrm{e}-3, \\
4.94 \mathrm{e}-3, \\
7.01 \mathrm{e}-3\end{array}$ & \\
\hline Density & $\mathrm{g} / \mathrm{cm}^{3}$ & 0.877 & 0.867 & 0.321 & $0.28,0.20,0.29$ & \\
\hline Log Kow & & 2.13 & 2.73 & 3.15 & $3.20,3.12,3.15$ & \\
\hline Log Koc & $\mathrm{cm}^{3} / \mathrm{g}$ & 1.81 & 2.41 & 2.83 & 2.84 & \\
\hline Koc 2 & $\mathrm{~L} / \mathrm{kg}$ & 79 & 190 & 468 & $405,422,357$ & \\
\hline $\begin{array}{l}\text { Vapor } \\
\text { pressure }\end{array}$ & $\begin{array}{l}\mathrm{mm} \mathrm{Hg} \\
\text { at } 68^{\circ} \mathrm{F}\end{array}$ & 75 & 20 & 10 & $7,9,9$ & \\
\hline $\begin{array}{l}\text { Vapor } \\
\text { pressure }\end{array}$ & $\begin{array}{l}\mathrm{mm} \mathrm{Hg} \\
\text { at } 25^{\circ} \mathrm{C}\end{array}$ & 95 & & 10 & $10,10,10$ & \\
\hline Formula & & $\mathrm{C}_{6} \mathrm{H}_{6}$ & $\mathrm{C}_{7} \mathrm{H}_{8}$ & $\mathrm{C}_{8} \mathrm{H}_{10}$ & $\mathrm{C}_{8} \mathrm{H}_{10}$ & \\
\hline $\begin{array}{l}\text { Molecular } \\
\text { weights }\end{array}$ & $\mathrm{g}$ & 78 & 92 & 106 & 106 & $95-111$ \\
\hline
\end{tabular}


Table 7: Notation

\begin{tabular}{|l|l|}
\hline Symbol & Definition \\
\hline$\rho_{B}$ & bulk density of dry-soil \\
$\rho_{\alpha}$ & $\alpha$-phase density \\
$k_{d}^{\gamma}$ & liquid-soil partitioning coefficient \\
$\omega_{\alpha}^{\gamma}$ & mass fraction of species $\gamma$ in phase $\alpha$ \\
$S_{\alpha}$ & liquid saturation of $\alpha$ phase \\
$\phi$ & porosity \\
$\mathbf{V}_{\alpha}$ & $\alpha$-phase velocity vector \\
$\mathbf{J}_{\alpha}^{\gamma}$ & hydrodynamic dispersive flux vector \\
$\mathbf{J}_{\alpha}^{* \gamma}$ & molecular diffusive flux vector \\
$\mathbf{D}_{h \alpha}^{\gamma}$ & dispersion tensor \\
$D_{\alpha}^{* \gamma}$ & diffusion coefficient \\
$k_{\alpha}$ & permeability function \\
$\mu_{\alpha}$ & $\alpha$-phase viscosity \\
$\mu_{m a x}$ & maximum hydrocarbon utilization rate per unit biomass \\
$p_{\alpha}$ & $\alpha$-phase pressure \\
$p_{c \alpha}$ & $\alpha$-phase retention pressure function \\
$c$ & hydrocarbon concentration \\
$o$ & oxygen concentration \\
$f$ & ratio of oxygen to hydrocarbon consumed \\
$K_{c}$ & hydrocarbon half saturation concentration \\
$K_{o}$ & oxygen half saturation concentration \\
$X$ & biomass concentration \\
\hline
\end{tabular}


The partial differential equations are solved in NUFT using integrated finite-difference method. At each time step the discretized system of nonlinear equations, including the nonlinear reactions, are solved using the NewtonRaphson method. Numerical simulations of bioventing are demonstrated for an axially symmetric $(r-z)$ domain with centrally located at injection well at Hill AFB site 280. Simulations are presented illustrating the sensitivities of remediation performance to the air injection rate and reaction rates. Specifically, model parameters at Hill AFB site 280 are calibrated using mass balance analysis.

\section{Model Geometry}

A cylindrical, axially symmetric coordinate system is used to describe the reactive transport around a single injection well. The geometrical model in the $x-z$ domain is shown in Figure 6 . The domain is rectangular, extending $93.2221 \mathrm{~m}$ horizontally and $33.5280 \mathrm{~m}$ vertically. The domain is vertically bounded by ground surface with constant infiltration and water table with constant saturation. The left boundary of the domain represents a injection well for oxygen supply.

As the figure shows, the study domain is discretized into $112 \times 17$ elements according to the distributed physical properties. $\Delta x$ and $\Delta z$, respectively in horizontal and vertical directions, are

$$
\mathrm{dx}=\left[\begin{array}{l}
0.10 \\
0.2700 \\
0.3645 \\
0.4921 \\
0.6643 \\
0.8968 \\
1.2107 \\
1.6344 \\
2.2065 \\
2.9787 \\
4.0213 \\
5.4288 \\
7.3288 \\
9.8939 \\
13.3568 \\
18.0317 \\
24.3428
\end{array}\right] \quad \mathrm{dz}=\left[\begin{array}{ll}
1.0 e-30 & \text { atmosphere } \\
20 \times 0.3048 & \text { sand } \\
10 \times 0.3048 & \text { sand with gravel and clay } \\
20 \times 0.3048 & \text { sand } \\
5 \times 0.3048 & \text { silty sand } \\
20 \times 0.3048 & \text { sand } \\
10 \times 0.3048 & \text { sand with gravel and clay } \\
25 \times 0.3048 & \text { sand } \\
1.0 e-30 & \text { water table } \\
& \\
& \\
&
\end{array}\right]
$$


The small vertical grid subdivisions at the atmosphere and water table are used to essentially eliminate vertical flow resistance in the cell layers, because these cells implement the constant or specified time-varying boundary conditions to the model.

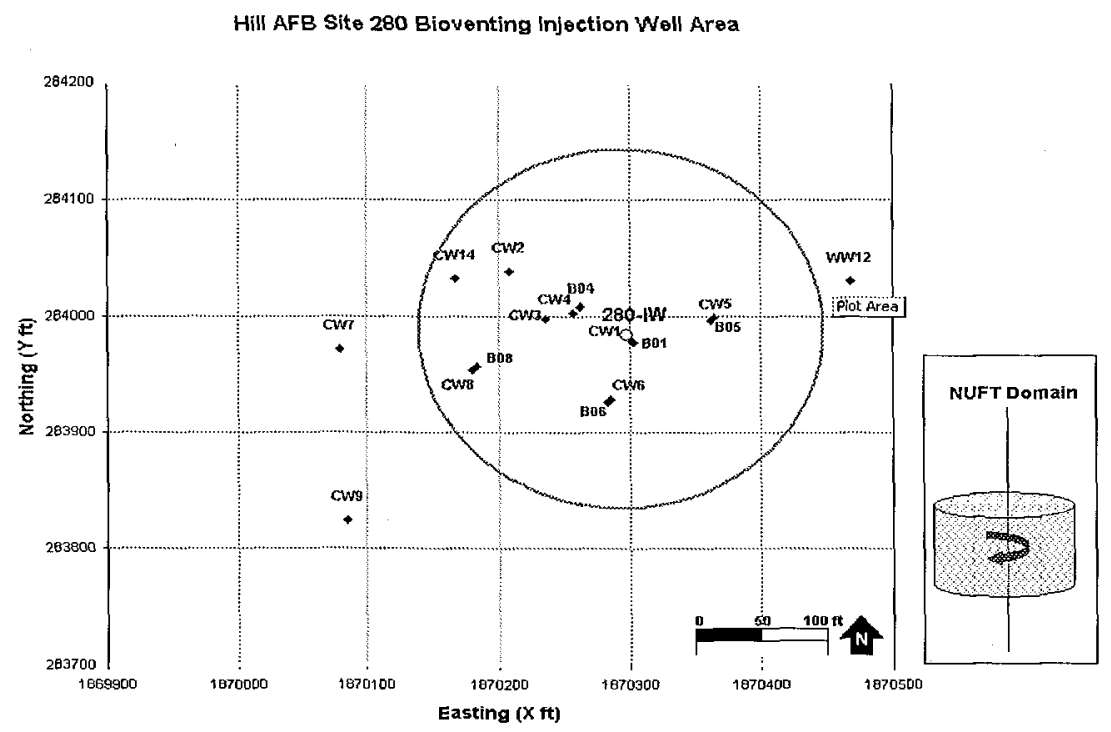

Figure 5: Study domain in $\mathrm{x} \sim \mathrm{y}$.

\section{Boundary conditions}

- Ground surface: A constant flow boundary, is used for liquid water flow (infiltration flux) at the ground surface boundary,

$$
\left.q\right|_{z=0}=1.9 \mathrm{in} / \mathrm{yr} .
$$

Air pressure is kept constant at atmospheric pressure. Concentrations of $\mathrm{O}_{2}, \mathrm{CO}_{2}$, and $\mathrm{N}_{2}$ are kept constant at nominal values for air, except for the the $N_{2}$ concentration which is slightly higher than nominal because it includes all non $\mathrm{O}_{2}$ and $\mathrm{CO}_{2}$ constituents. Liquid saturation and benzene concentration at the surface are kept fixed at zero.

- Water table: Constant pressure and saturation are assumed. The pressure at the water table equals the atmospheric pressure plus the weight of the vadose zone air column. The actual value is determined by the initialization run described in the next section. 
- Injection well: Air is injected at the well located in the center of the model. The well screen is from $23.2 \mathrm{ft}$ to $108.2 \mathrm{ft}$. The air injection rate is shown in figure 7 as a function of time.

\section{Initial conditions}

An isothermal condition $\left(T=20^{\circ} \mathrm{C}\right)$ is assumed. The initial conditions for gas pressure, saturation, concentrations of water, air, $\mathrm{O}_{2}$, and $\mathrm{CO}_{2}$, in both liquid and gas phases are obtained by performing an initialization run until a steady state is reached. The resulting pressure and saturation profiles from ground surface to water table are shown in figure 8 .

In the initialization and main runs, an infiltration rate of $1.9 \mathrm{in} / \mathrm{yr}$ was used. Although no specific infiltration rates are available at Site 280, the annual average precipitation over the whole air force base from 1979 to 1988 is 19 inches according to the Hill AFB precipitation data (Montgomery Watson, 1995).

Benzene concentrations, as shown in Figure 9, are from analysis of field data and, then, imposed on the results of the initialization run in order to obtain the complete set of initial conditions for the main run.

\section{Model calibration}

In the model calibration process, the reaction rate, $\beta$ as defined in (9), was calibrated to match plume size and total mass removal. The ratio of oxygen to hydrocarbon consumed, $f$, is calculated based on the reaction (6). The half saturation concentrations of oxygen and benzene are assumed to be constant over both time and space (Sun et al., 1998) The reaction rate was initially selected based on literature data (Sun et al., 1998), $\beta=5.301 e-08 \mathrm{moles} / \mathrm{m}^{3} \mathrm{~s}$, which reflects the reaction rate in saturated aquifers, and the final calibrated reaction rate is $\beta=1.13 e-09$ moles $/ \mathrm{m}^{3} \mathrm{~s}$. This result of the reaction rate reflects the fact that biodegradation rate is lower in unsaturated zone than in saturated zone.

\section{Simulation results}

\section{Concentration profiles of benzene}

Multiphase and multi-species reactive transport simulations were conducted for 2000 days to predict contaminant concentration and to evaluate bioventing 


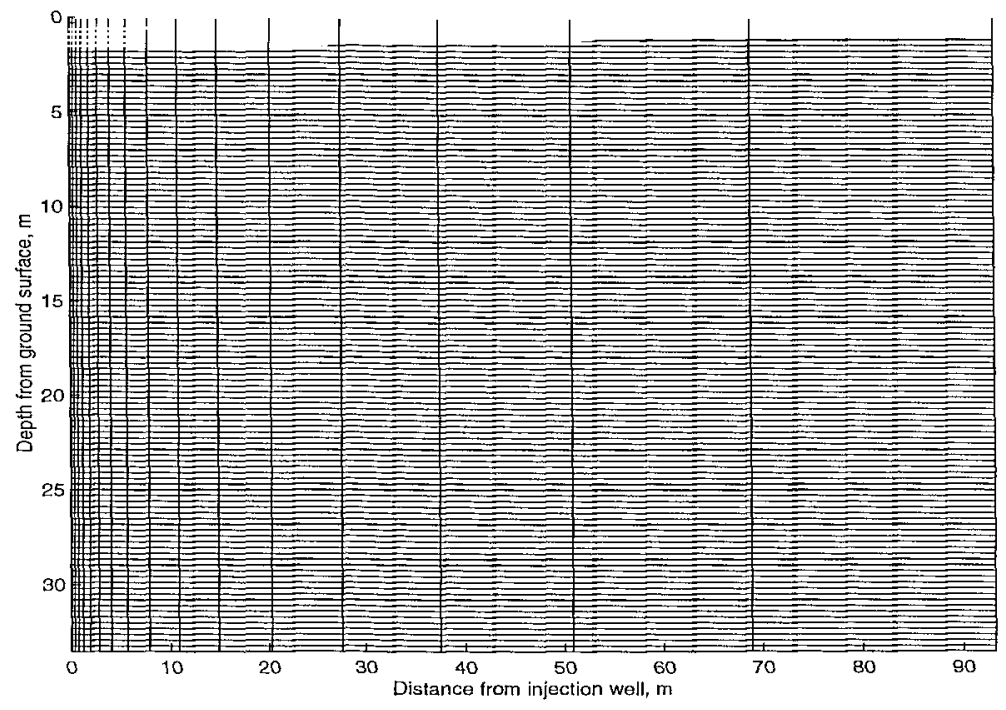

Figure 6: Study domain in $\mathrm{x} \sim \mathrm{y}$ and finite-difference elements.

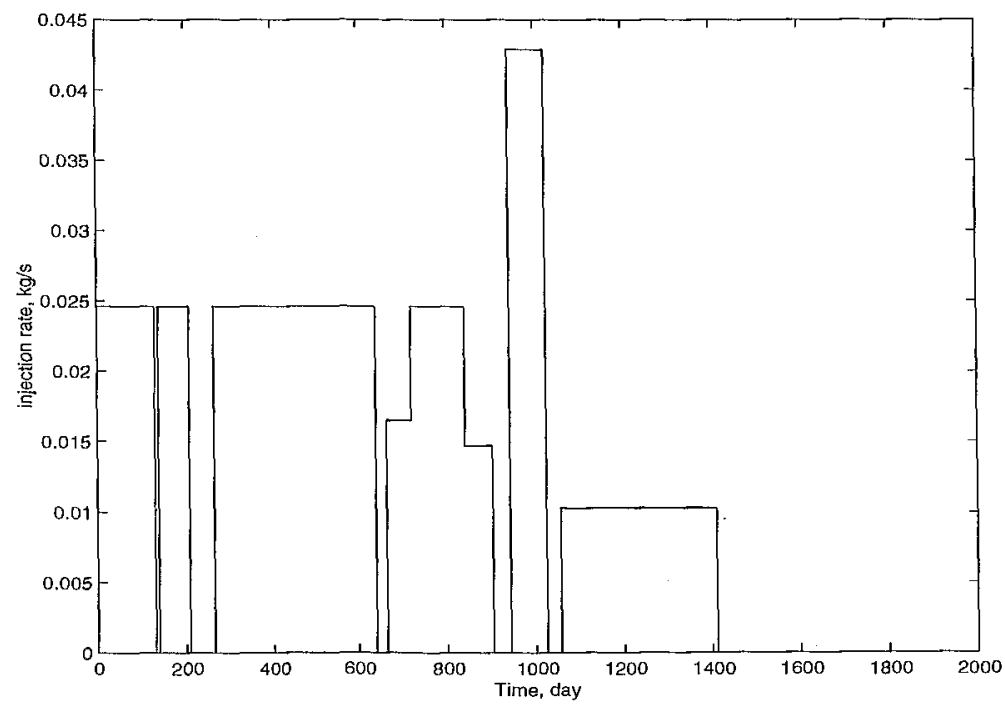

Figure 7: Injection rate vs. time. 


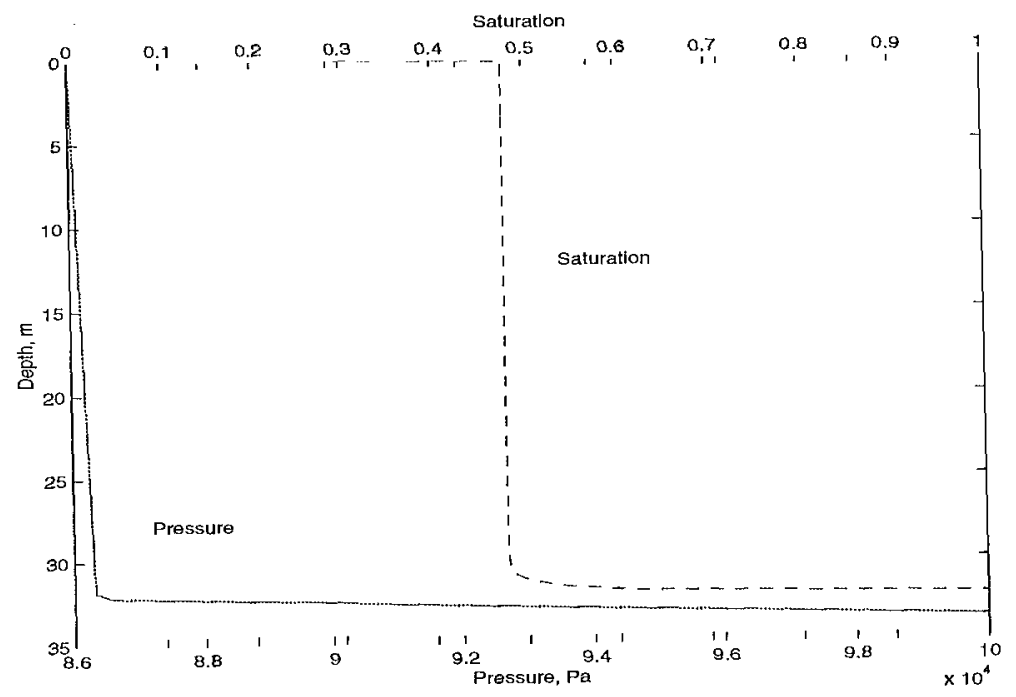

Figure 8: Initial pressure and saturation.

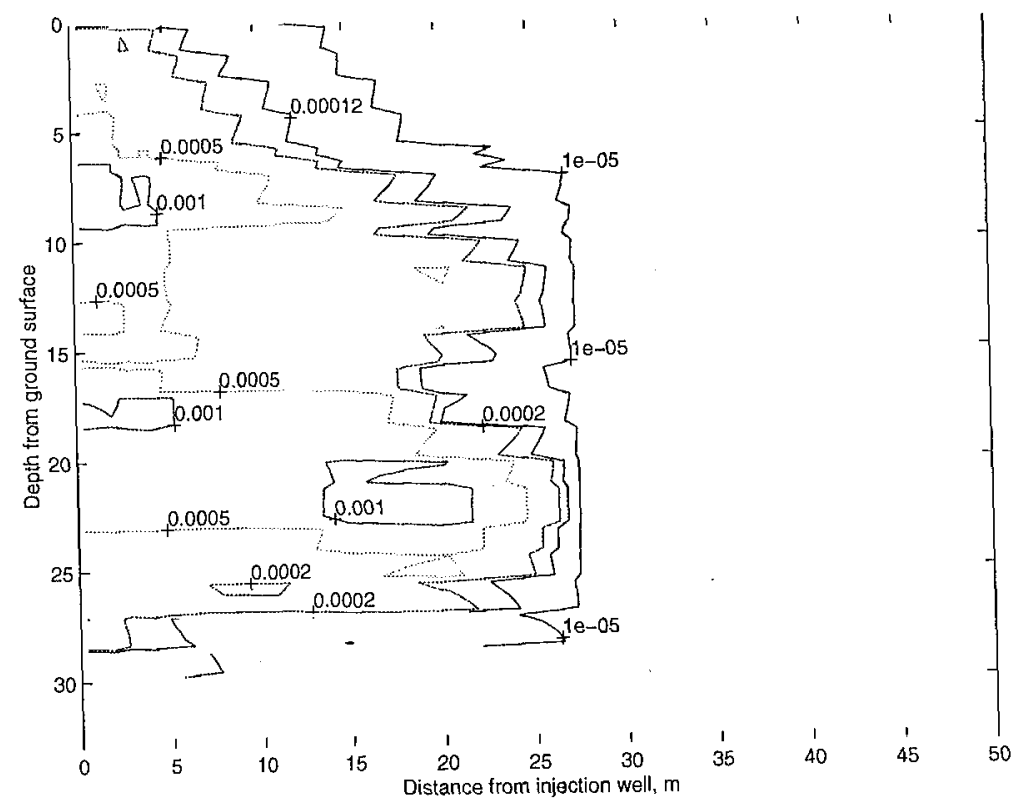

Figure 9: Initial Benzene Concentrations ( $\mathrm{kg} / \mathrm{kg}$ soil). 
efficiency. Based on the mass balance analysis, the lumped reaction rate was calibrated. The corresponding concentration profiles in various time steps are shown in Figures 10 through 16.

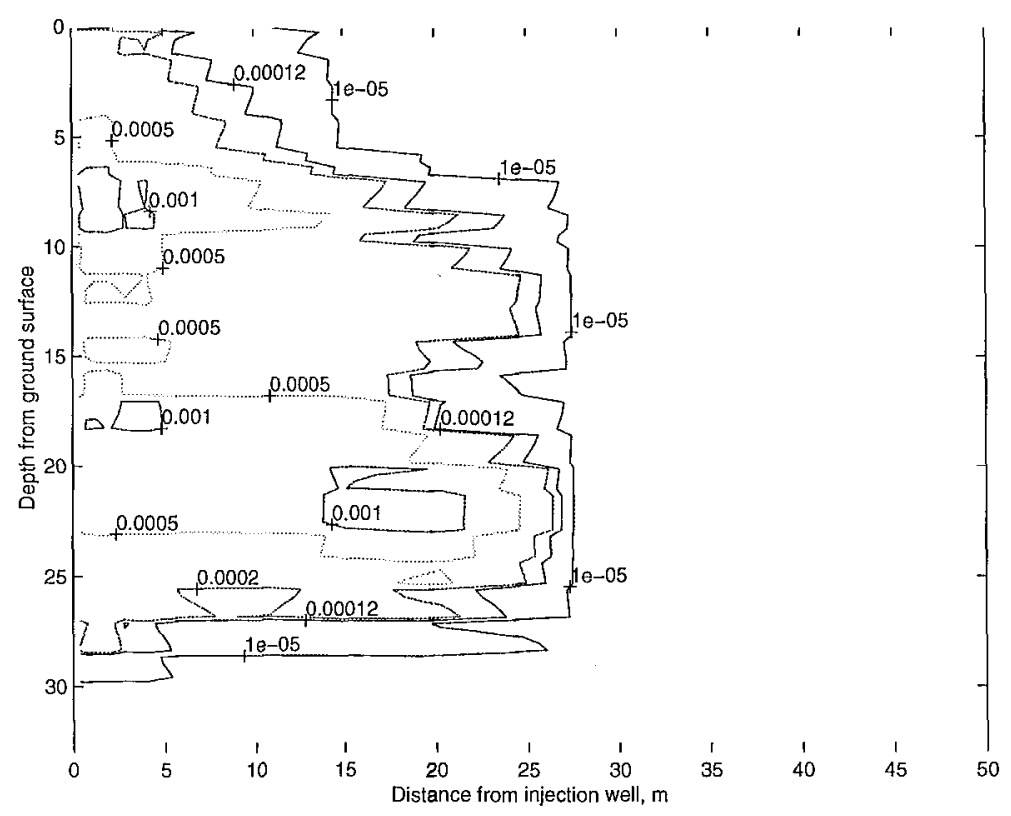

Figure 10: Benzene Concentrations ( $\mathrm{kg} / \mathrm{kg}$ soil) after 1 month bioventing. 17.

The history profiles of absorbed benzene concentration are shown in Figure

\section{Mass balance analysis}

The total mass of a contaminant absorbed on soil surface is calculated as:

$$
m_{t}=2 \pi \int_{z} \int_{r} r \rho_{B}(z) c_{s}(r, z) d r d z .
$$

The total mass of benzene absorbed on soil surface before and after bioventing performance are, respectively, measured as $20763.0 \mathrm{~kg}$ and $90.98 \mathrm{~kg}$. According to the in situ respiration test data at well 280-CW1 (20-ft depth) from April 1991 through November 1994 (Montgomery Watson, 1995) the lumped biodegradation rate was estimated in Table 8.

If we use the average biodegradation rate without considering transport processes, the total mass absorbed can be approximately as,

$$
\hat{m}_{t}=m_{t}^{o} \exp (-\bar{\lambda} t),
$$




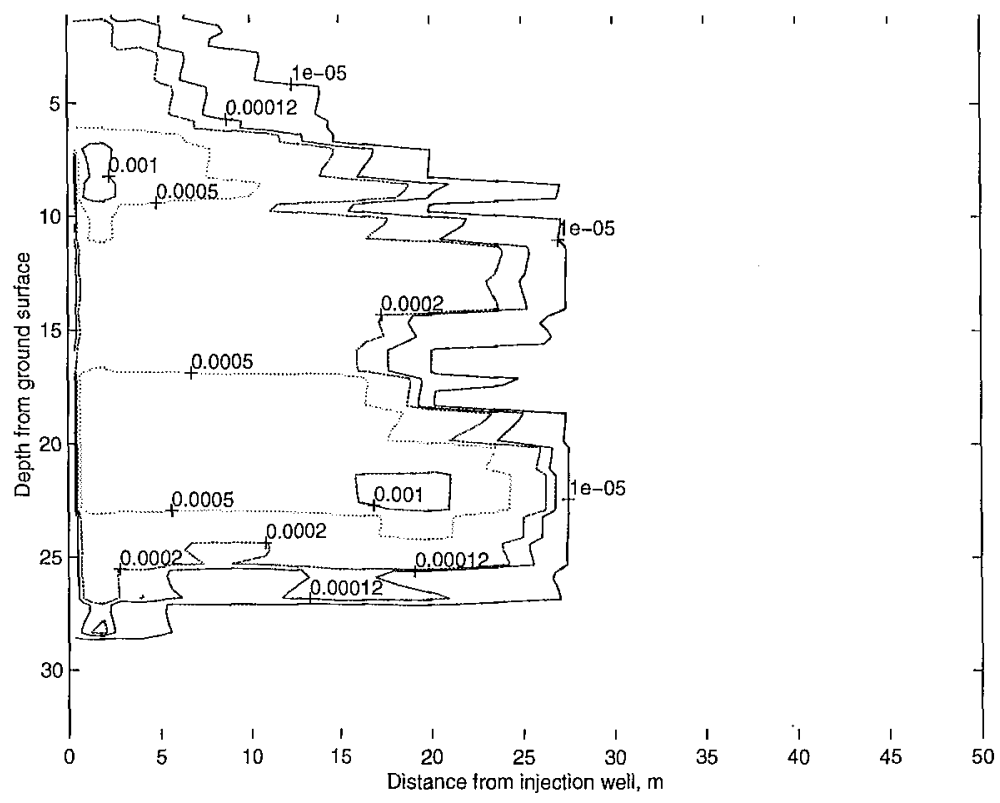

Figure 11: Benzene Concentrations ( $\mathrm{kg} / \mathrm{kg}$ soil) after 6 month bioventing.

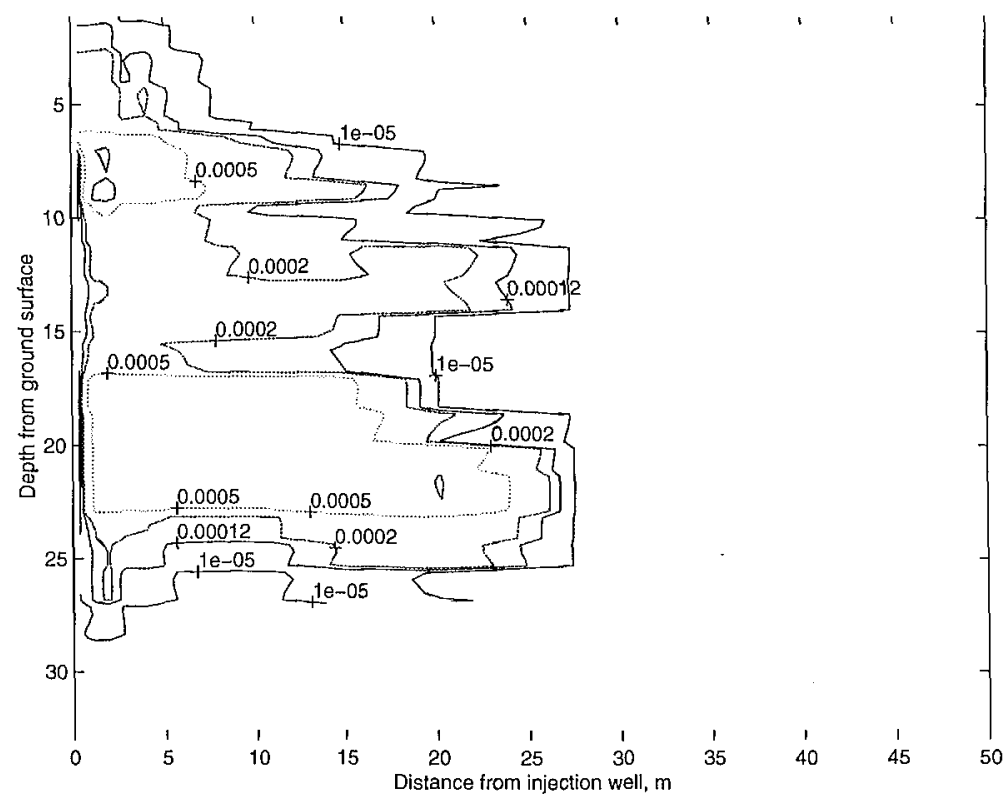

Figure 12: Benzene Concentrations ( $\mathrm{kg} / \mathrm{kg}$ soil) after 1 year bioventing. 


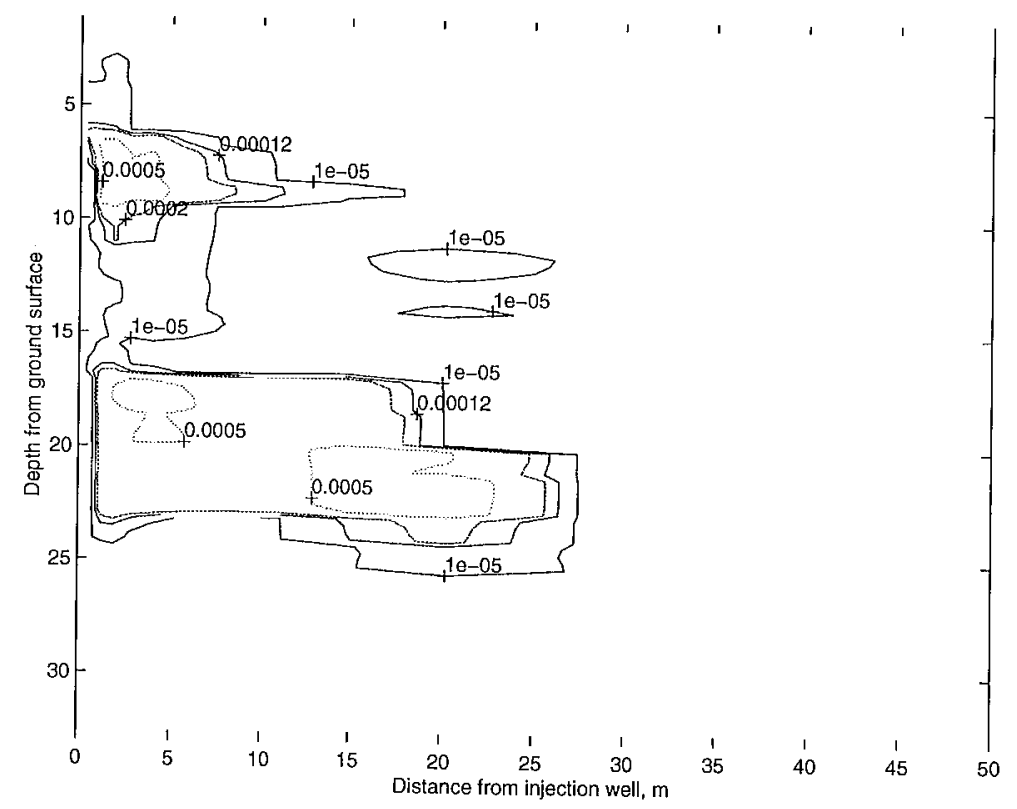

Figure 13: Benzene Concentrations ( $\mathrm{kg} / \mathrm{kg}$ soil) after 2 year bioventing.

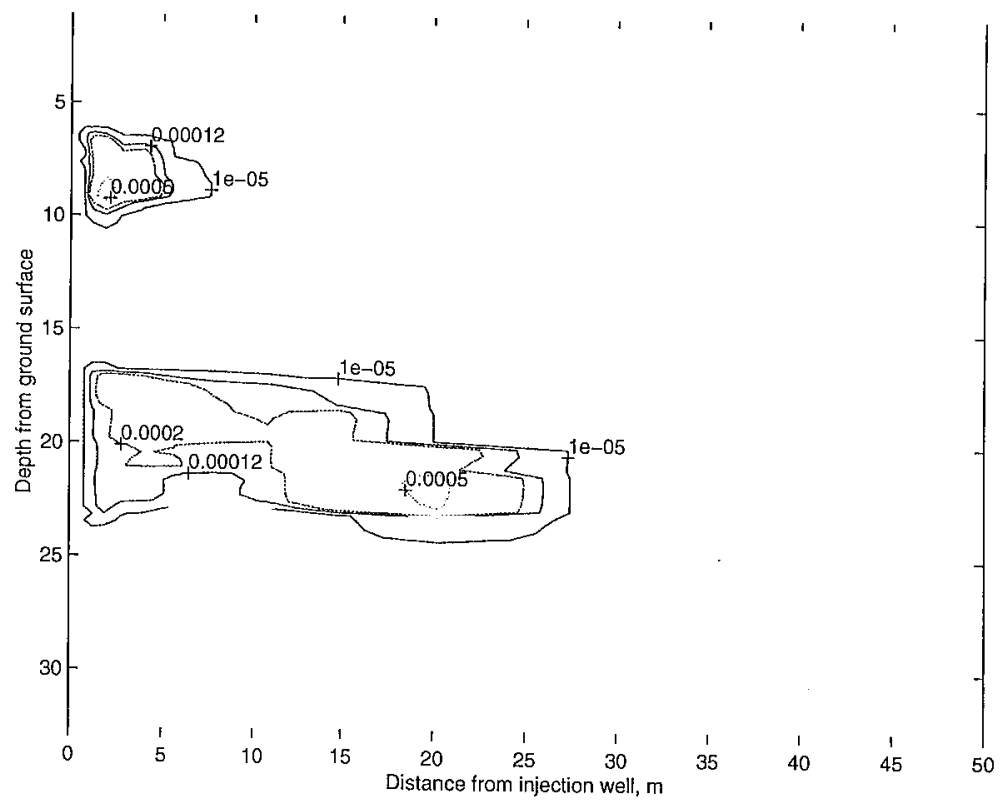

Figure 14: Benzene Concentrations ( $\mathrm{kg} / \mathrm{kg}$ soil) after 3 year bioventing. 


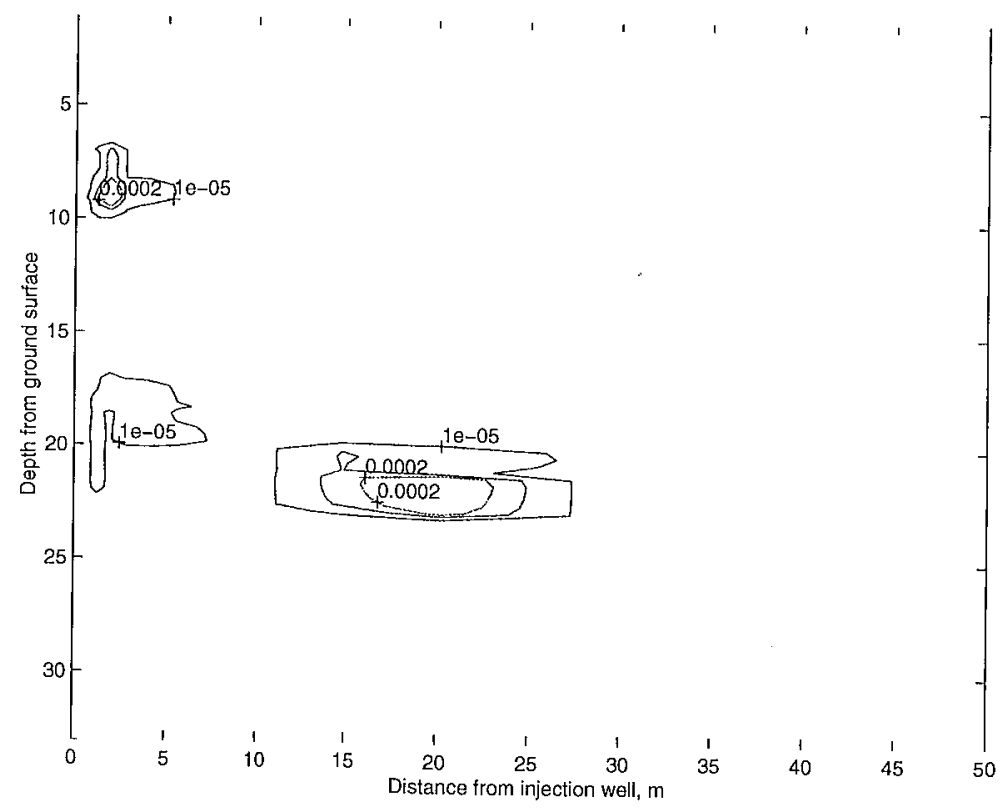

Figure 15: Benzene Concentrations ( $\mathrm{kg} / \mathrm{kg}$ soil) after 4 year bioventing.

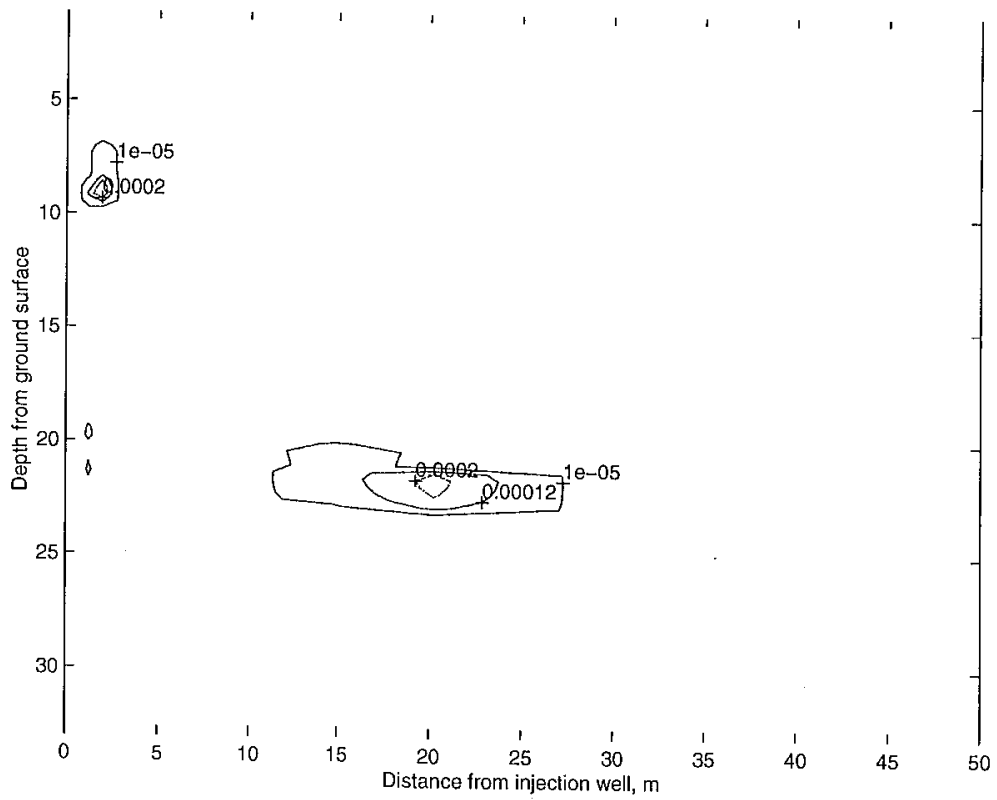

Figure 16: Final Benzene Concentrations (kg/kg soil). 


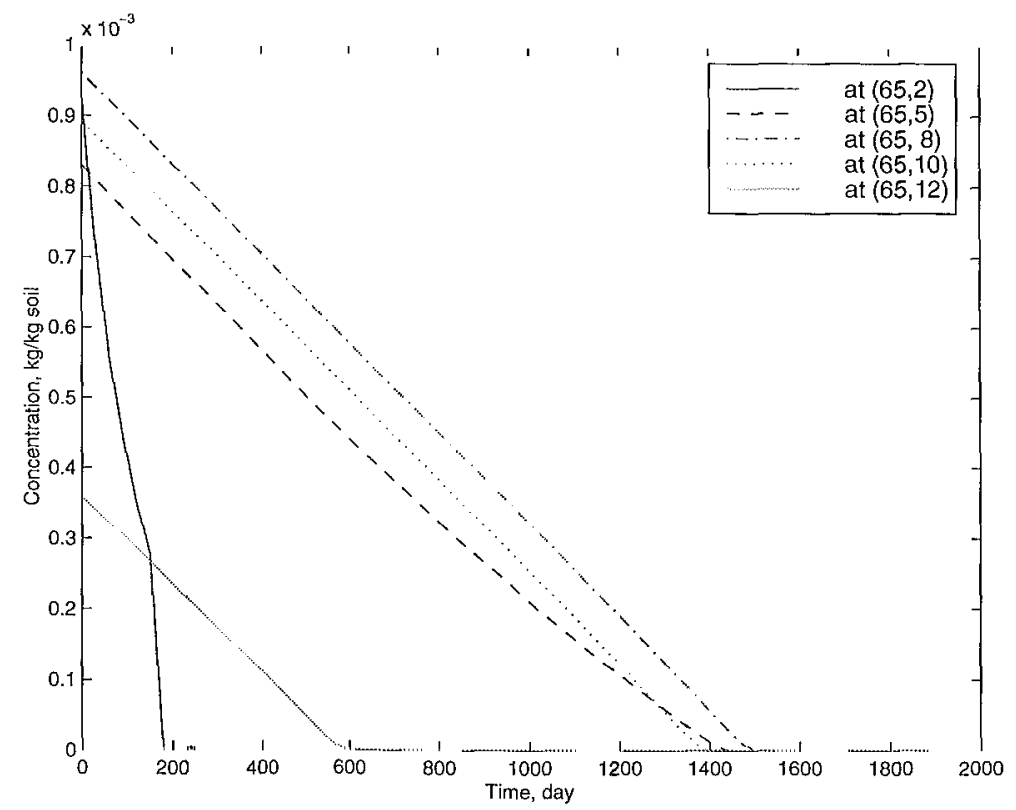

Figure 17: Benzene Concentrations (kg/kg soil) vs. time.

Table 8: Biodegradation rates from respiration test at Well 280-IW1 (20-ft depth)

\begin{tabular}{|l|c|c|c|c|c|c|}
\hline Measurement & 1 & 2 & 3 & 4 & 5 & Average \\
\hline Time (day) & $0 \sim 129$ & $130 \sim 575$ & $576 \sim 813$ & $814 \sim 914$ & $915 \sim 1236$ & $0 \sim 1236$ \\
Rate $(\mathrm{mg} / \mathrm{kg} / \mathrm{d})$ & 2.27 & 0.313 & 0.164 & 0.193 & 0.151 & 0.43655 \\
\hline
\end{tabular}


where $m_{t}^{o}$ is the initial benzene mass and $\bar{\lambda}$ is the average biodegradation estimated through respiration tests. Figure 18 shows the comparison between the total mass simulated using NUFT and the total mass estimated using respiration tests. The simulated total mass of absorbed benzene is $87.6785 \mathrm{~kg}$

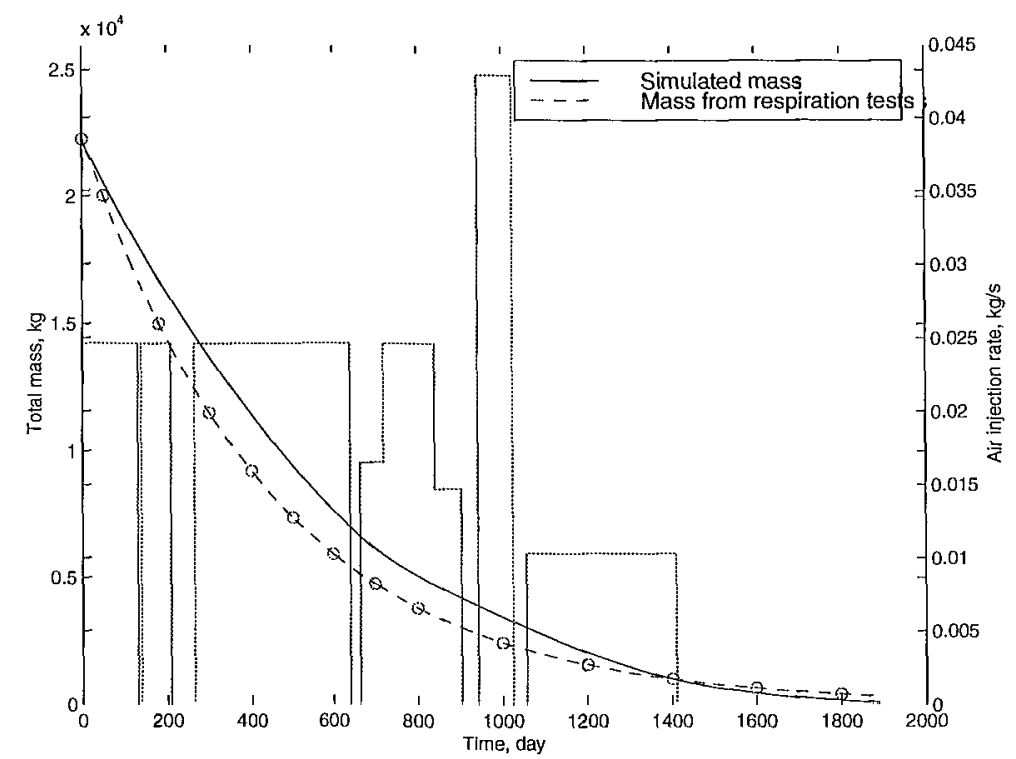

Figure 18: Total mass of benzene left in the subsurface.

in the cylindrical domain.

\section{Benzene concentration distribution without bioventing action}

In this section, we examine the performance of natural attenuation if the bioventing system were not implemented, and then demonstrate that oxygen is a limiting factor for natural biochemical activity. As shown in Figure 19, benzene concentrations in five years are predicted using the USNT module.

Figure 20 shows the significant difference of total benzene mass left in the vadose zone under natural attenuation and bioventing action. If the bioventing system were not implement, the total mass of benzene left in the vadose zone could be $1.8816 e+04$. Natural attenuation could destroy $15.42 \%$ of initial mass while bioventing action can remove $99.61 \%$ mass. 


\section{Conclusions}

A conceptual model of bioventing remediation that incorporates multiphase flow processes and biological reactions was presented. The conceptual model was implemented in a new version of the NUFT code, and its documentation is presented in the Appendix to this report. The use of the numerical model was applied to an actual bioventing site at the Hill AFB. Our simulations indicate the sensitivity of model predictions, such as contaminant concentrations and biodegradation efficiency, to maximum substrate utilization and air injection rate. Comparison with the non-remediated case versus the remediated case, using calibrated bio-reaction parameters, demonstrated the effectiveness of bioventing over natural attenuation.

Comparison with the mass removal data at Hill AFB is limited by the fact that sufficiently accurate contaminant mass estimates based on coring are available only at two points in time. Further analysis of vapor extraction data may lead to improved estimates of actual contaminant history, which could then be used for model comparisons. At this stage, average decay rates were used to obtain an estimated time history for model comparison. 


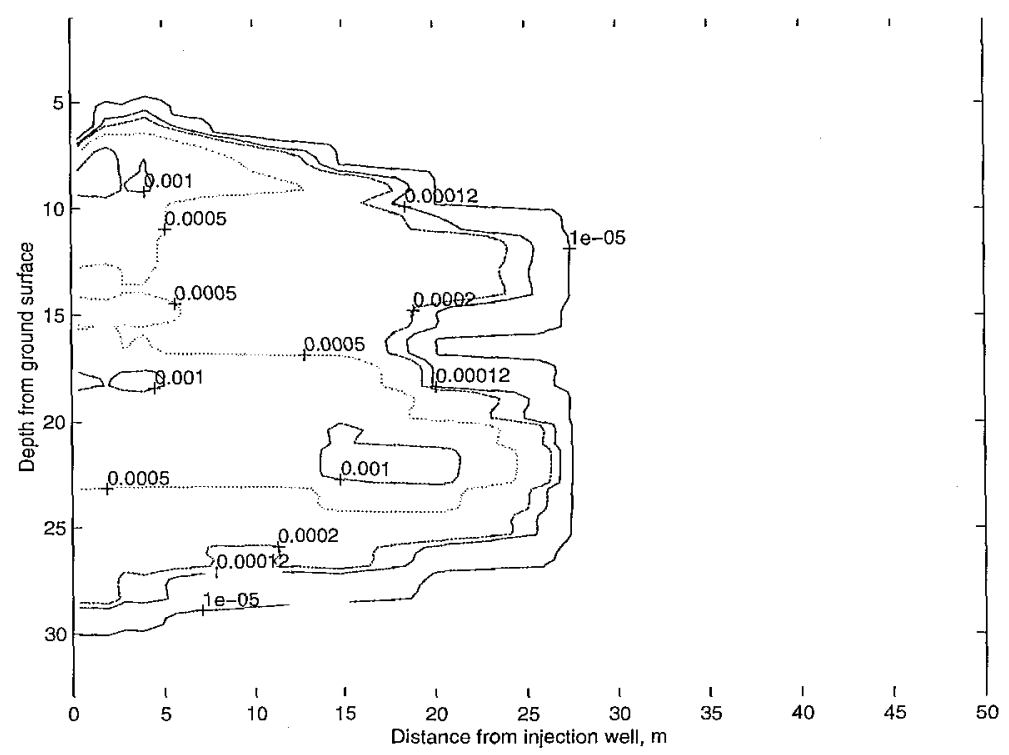

Figure 19: Concentration profile of benzene after 5 years without bioventing action.

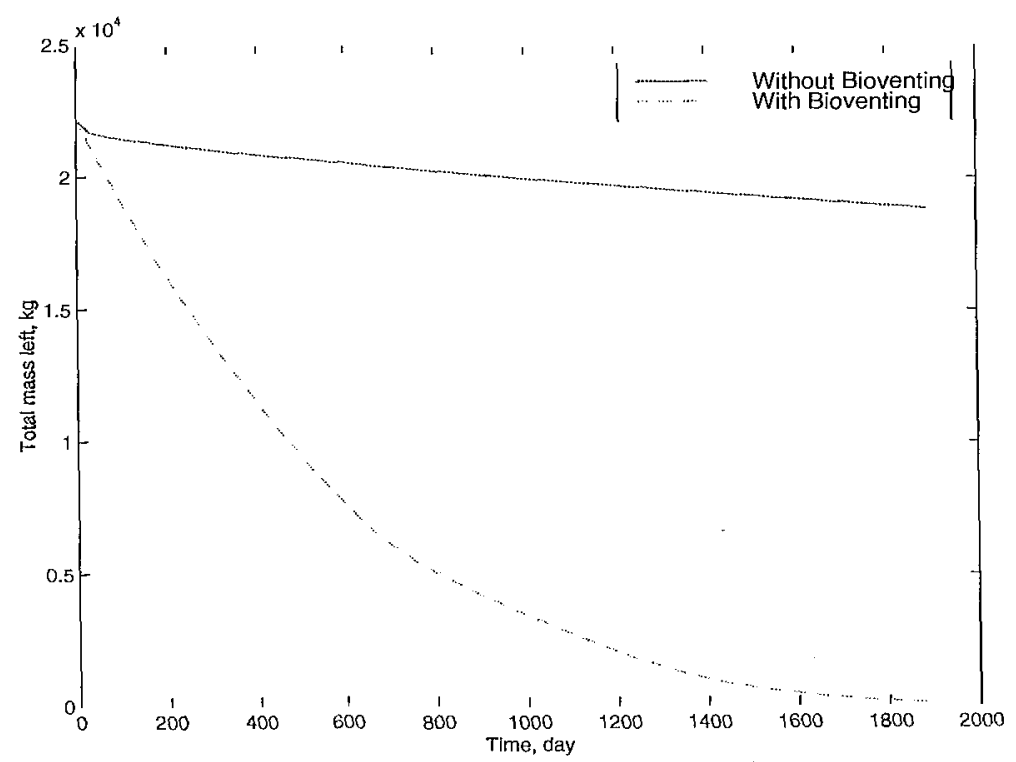

Figure 20: Total benzene mass left with and without bioventing action. 


\section{Bibliography}

[1] Battelle, 1991, Site characterization report for the Hill Air Force Base Site 280 fuel (JP-4) storage lot.

[2] Battelle, 1992, Final report on additional investigation of the 280 fuels storage lot for application of low intensity bioreclamation, Hill Air Force Base, Utah.

[3] Battelle, 1993, Bioremediation of hazardous wastes at CERCLA and RCRA sites: Hill Air Force Base Site 280 low-intensity bioreclamation, second annual report.

[4] Battelle, 1994, Bioremediation of hazardous wastes at CERCLA and RCRA sites: Hill Air Force Base Site 280 low-intensity bioreclamation, final report.

[5] Battelle, 1995, Evaluation of bioventing as a remedial alternative at the Hill Air Force Base 280 Site.

[6] Baehr, A. L., Stackelberg, P. E., Baker, R. J., 1999, Evaluation of the atmosphere as a source of volatile organic compounds in shallow groundwater, Water Resources Research 35(1), 127-136.

[7] Bear, J., 1979, Groundwater hydraulics, McGraw-Hill, New York.

[8] Bioremediation Field Initiative Site Profile: Hill Air Force Base Superfund Site., 1995, EPA/540/F-95/506C.

[9] Borden, R. C., Bedient, P. B., 1986, Transport of dissolved hydrocarbon influenced by reaeration and oxygen limited biodegradation: Theoretical development, Water Resources Research 22, 1973-1982.

[10] Clement, T. P., Sun, Y., Hooker, B. S., Petersen, J. N., 1998, Modeling multispecies reactive transport in groundwater aquifers, Groundwater Monitoring and Remediation 18(2), 79-92.

[11] Culver, T. B., Shoemaker, C. A., Lion, L. W., 1991, Impact of vapor sorption on the subsurface transport of volatile organic compounds: A numerical model and analysis, Water Resources Research 27(9), 2259-2270.

[12] Downey, D. C., Hall, J. F., and Miller, R. N., Bioventing in low permeability soils. 
[13] Dupont, R. R., Doucette, W. J., and Hinchee, R. E., 1995, Assessment of in situ bioremediation potential and the application of bioventing at a fuel-contaminated site, In Situ Bioreclamation.

[14] Lu, G.; Clement, T. P.; Zheng, C.; Wiedemeier, T. H., 1999, Natural Attenuation of BTEX Compounds: Model Development and Field-Scale Application, Ground Water, in press.

[15] McNab, W. W. Jr., Narasimhan, T. N., 1993, A multiple species transport model with sequential decay chain interactions in heterogeneous subsurface environments, Water Resources Research 29(8), 2737-2746.

[16] Molz, F. J., Widdowson, M. A., Benefield, L. D., 1986, Simulation of microbial growth dynamic coupled to nutrient and oxygen transport in porous media, Water Resources Research 22(8), 1207-1216.

[17] Montgomery Watson, 1994, Subsurface investigation report, corrective action plan, and free product removal report for UST Site 260 (ST74).

[18] Montgomery Watson, 1995, Subsurface investigation report, corrective action plan, and free product removal report for UST Site 280 (ST35; EFTP).

[19] Nitao, J. J., 1998a, Reference manual for the NUFT flow and transport code, version 2.0, Lawrence Livermore National Laboratory, Livermore, CA (UCRLMA-130651).

[20] Nitao, J. J., 1998b, User's manual for USNT module of the NUFT code, version 2.0, (NP-phase, NC-component, thermal), Lawrence Livermore National Laboratory, Livermore, CA, (UCRL-MA-130653).

[21] Rifai, S. H., Bedient, P. B., 1990, Comparison of biodegradation kinetics with an instantaneous reaction model for groundwater, Water Resources Research 26(4), $637-645$.

[22] Shoemaker, A. C., Culver, T. B., Lion, L. W., Peterson, M. G., 1990, Analytical models of the impact of two-phase sorption on the subsurface transport of volatile chemicals, Water Resources Research 26(4), 745-758.

[23] Sun, Y., J.N. Petersen, T.P. Clement, and B.S. Hooker, 1998, Effects of reaction kinetics on predicted concentration profiles during subsurface bioremediation, $J$. of Contaminant Hydrology 31(3), 147-162.

[24] van Genuchten, M.Th., Leij, F.J., Yates, S.R., 1991, The RETC code for qualifying the hydraulic functions of unsaturated soils, U.S. Salinity Laboratory, Riverside, CA.

[25] Wiedemeier, T.H., Miller, R.N., Wilson, J.T., and Kampbell D.H., 1995, Significance of anaerobic processes for the intrinsic Bioremediation of fuel hydrocarbons. 
[26] Wiedemeier, Wilson, J.T., T.H., Miller, R.N., and Kampbell D.H., 1995. United States Air Force guidelines for successfully supporting 819 intrinsic remediation with an example from Hill Air Force Base.

[27] Wiedemeier, T. H., Wilson, J.T., Kampbell, D.H., Miller, R.N., Hansen, J.E., 1995 Technical protocol for implementing intrinsic remediation with long-term monitoring for natural attenuation of fuel contamination dissolved in groundwater., Air Force Center for Environmental Excellence, Technology Transfer Division.

[28] Waddill, D. W., Widdowson, M. A., 1998, Three-dimensional model for subsurface transport and biodegradation, J. of Environ. Eng. 124(4), 336-344.

[29] Xu, T., Gerard, F., Pruess, K., Brimhall, G., 1997, Modeling non-isothermal multiphase multispecies reactive chemical transport in geological media, Lawrence Berkeley National Laboratory, LBNL-40504, UC-400.

[30] Xu, T., Samper, J., Ayora, C., Manzano, M., Custodio, E., 1999, Modeling of non-isothermal multi-component reactive transport in field scale porous media flow systems, Journal of Hydrology 214, 144-164. 


\section{Appendix: Documentation of Monod Kinetics Option in the NUFT Code}

The Monod kinetics implemented in the NUFT code can encompass any number of reactions. Moreover, the original Monod law has been extended to encompass various modifications that are currently being used by modelers, such as multiple Monod reactions and multiple inhibition factors.

Consider the general set of reactions represented symbolically as

$$
\sum_{\gamma} \nu_{r}^{\gamma} \mathcal{A}^{\gamma}=0, \quad r=1, \ldots, N R
$$

where $\mathcal{A}^{\gamma}$ represents the chemical formula for the $\gamma$-th species, and $\nu_{r}^{\gamma}$ is the stoichiometric coefficient of the $\gamma$-th species in the $r$-th reaction. By convention, $\nu_{r}^{\gamma}$ is negative for reactants and positive for products. If the $\gamma$-th species does not take part in the $r$-th reaction, then $\nu_{r}^{\gamma}$ is zero.

For example, the reaction given by (6) is represented as

$$
-\mathrm{C}_{6} \mathrm{H}_{6}-7.5 \mathrm{O}_{2}+6 \mathrm{CO}_{2}+3 \mathrm{H}_{2} \mathrm{O}=0 \text {. }
$$

The following mass balance equation for the $\gamma$-th species with reactions has been implemented into the NUFT code,

$$
\begin{aligned}
& \frac{\partial}{\partial t}\left(\sum_{\alpha} \phi S_{\alpha} \rho_{\alpha} \omega_{\alpha}^{\gamma}+\rho_{B} k_{d}^{\gamma} \rho_{\ell} \omega_{\ell}^{\gamma}\right) \\
& \quad+\sum_{\alpha} \nabla \cdot \phi S_{\alpha}\left(\rho_{\alpha} \omega_{\alpha}^{\gamma} \mathbf{V}_{\alpha}+\mathbf{J}_{\alpha}^{\gamma}+\mathbf{J}_{\alpha}^{* \gamma}\right)=M^{\gamma} \sum_{r} \phi \rho_{\alpha_{r}} S_{\alpha_{r}} \nu_{r}^{\gamma} f_{r} .
\end{aligned}
$$

Most of the symbols in this equation are defined in Table 7 . The symbols that are not, are given by the following,

$r \quad$ summation index over all reactions,

$\alpha_{r} \quad$ phase in which the $r$-th reaction occurs,

$f_{r} \quad$ reaction rate of the $r$-th reaction in moles

per mass of $\alpha_{r}$-phase per second,

$M^{\gamma}$ molecular mass of the component.

The general form of the reaction rate law implemented into NUFT is the following,

$$
\begin{aligned}
f_{r}=k_{\max } & \cdot\left(\frac{\omega_{1}}{s_{1}+\omega_{1}}\right) \cdot\left(\frac{\omega_{2}}{s_{2}+\omega_{2}}\right) \cdot\left(\frac{\omega_{3}}{s_{3}+\omega_{3}}\right) \cdot \ldots \\
& \cdot\left(\frac{b_{1}}{b_{1}+\omega_{1}}\right) \cdot\left(\frac{b_{2}}{b_{2}+\omega_{2}}\right) \cdot\left(\frac{b_{3}}{b_{3}+\omega_{3}}\right) \cdot \ldots \\
& \cdot \omega_{1}^{a_{1}} \cdot \omega_{2}^{a_{2}} \cdot \omega_{3}^{a_{3}} \cdot \ldots \\
& \cdot \exp \left(-\frac{E}{R T}\right) / \exp \left(-\frac{E}{R\left(T_{0}+273.15\right)}\right)
\end{aligned}
$$


$f_{r}$ reaction rate of the $r$-th reaction $(\mathrm{mol} / \mathrm{kg}-\mathrm{s})$,

$T$ temperature (Kelvin),

$T_{0}$ reference temperature (Centigrade)

$\omega_{i}$ mass fractions (to use mole fractions instead, see below),

$E$ activation-energy-type constant $(\mathrm{J} / \mathrm{mol})$,

$R$ gas constant $(\mathrm{J} / \mathrm{mol}-\mathrm{K})$,

$s_{i} \quad$ saturation constants $(\mathrm{kg} / \mathrm{kg})$,

$b_{i}$ inhibition constants $(\mathrm{kg} / \mathrm{kg})$,

$a_{i}$ powers,

$i \quad$ index running only over those species taking part in the reaction.

The following data block in the input file of the USNT module specifies the parameters in the above reaction rate law.

\section{; ; specify the kinetic reactions}

(reactions

; ; specify a reaction, more than one reaction can be specified by

; ; specifying more set blocks

(set

; ; name of reaction, used only for output purposes

(name <name-of-reaction>)

; ; name of the fluid phase in which reaction occurs

(phase <fluid-phase>)

; ; names of species (components) which take part in the reaction,

;; these names are the same as the components in (init-eqts...);

;; but not all species need occur, only those that take part in the

; ; reaction

(species <species_1> <species_2〉 ...)

; ; stoichiometric coefficients of the above species in that order

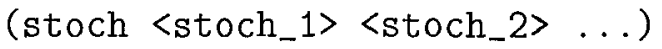

; ; specify the type of rate law and its parameters

(rate monod

$$
\begin{aligned}
& \text { (maxrate <k-value >) ; maximum transformation rate. } \\
& \text {; ; (moles / kg-s) } \\
& \text { (sat-consts ; saturation constants } k_{-} i \text {, } \\
& \langle\text { s1 }\rangle\langle\mathrm{s} 2\rangle \ldots) \quad \text {; ; can be set to zero to skip } \\
& \text {; ; Monod law for the particular } \\
& \text {; ; species. ( } \mathrm{kg} / \mathrm{kg}) \\
& \text { (powers }\left\langle a_{-} 1\right\rangle\left\langle a_{-} 2\right\rangle \ldots \text {...) ; c concentration powers optional, } \\
& \text {;; default is a_i's all zero. } \\
& \text {; ; (unitless) }
\end{aligned}
$$




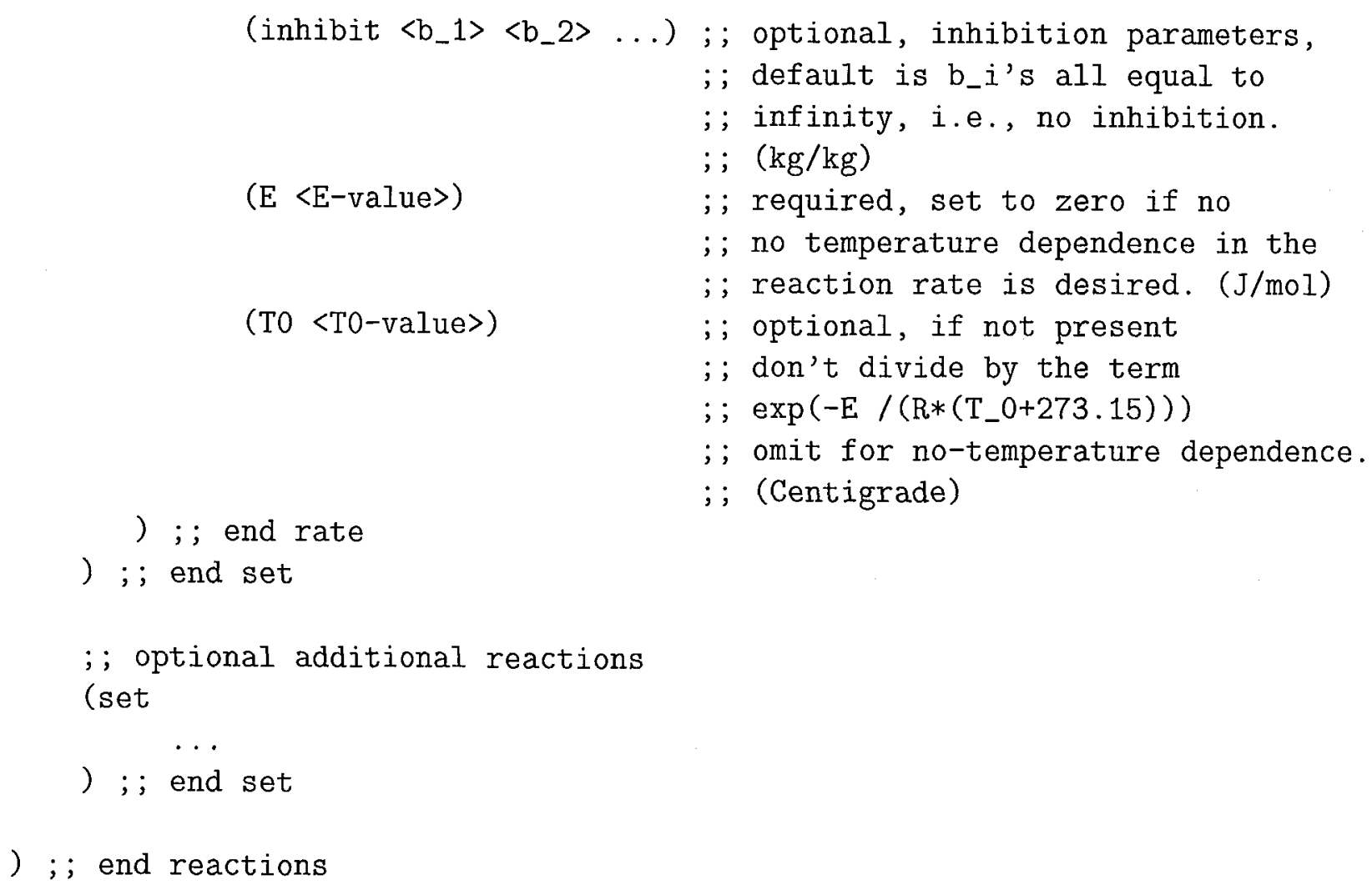

Notes:

1. The parameters for sat-consts, powers, and inhibit are defined for the species in the same order as specified in the (species...) data block.

2. The "activation energy" parameter $E$ is in units of $\mathrm{J} / \mathrm{mol}$, not kcal/mol.

3. If the T0 parameter is not present, then the denominator $\exp \left(-E / R\left(T_{0}+\right.\right.$ 273.15)) will not be present in the rate law, although the numerator $\exp (-E / R T)$ will be present. If the no exponential temperature dependence is desired, set $E$ to zero and omit the To parameter.

4. The absolute temperature $T$ in Kelvin in the above equations is supplied internally by NUFT. For isothermal models the temperature in Centigrade set in the (generic...) data block is used after the code internally converts to Kelvin.

5 . Whenever the saturation of the phase in which the reaction occurs reaches zero, i.e., the phase disappears, the rate for the reaction is set to zero. 
6. The concentrations $\omega_{i}$ 's are in mass fraction; if mole fraction is desired in the rate law instead, include the flag (rate-law-mole-fraction on) in the input file. If this option is selected, then the required units of the $k_{i}$ 's and $b_{i}$ 's in the sat-consts and inhibit input parameters change from $(\mathrm{kg} / \mathrm{kg})$ to $(\mathrm{mol} / \mathrm{mol})$ instead. The units of the maxrate parameter is unchanged.

\section{Example:}

Consider the following species: $A, B, D, E$ with the reaction,

$$
A+2 B \Rightarrow D
$$

with inhibition by species $\mathrm{D}$ and a fourth species $\mathrm{E}$, which is not a reactant or product of the reaction. If the resulting rate law is given by,

$$
f_{r}=\left(1.3 \times 10^{-3}\right)\left(\begin{array}{c}
\omega_{A} \\
0.02+\omega_{A}
\end{array}\right)\left(\frac{3}{3+\omega_{E}}\right)\left(\begin{array}{c}
4 \\
4.0+\omega_{D}
\end{array}\right) \omega_{B}^{2},
$$

the proper NUFT input data for the reaction is

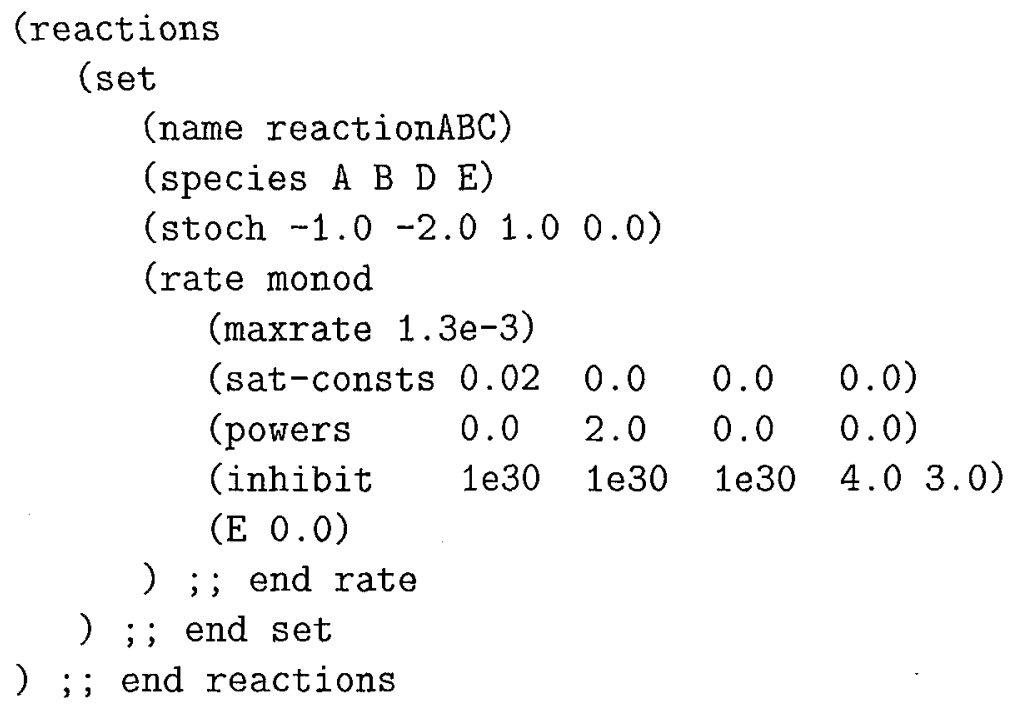

